\title{
Modeling ocean circulation and biogeochemical variability in the Gulf of Mexico
}

\author{
Z. Xue ${ }^{1}$, R. He ${ }^{1}$, K. Fennel ${ }^{2}$, W.-J. Cai ${ }^{3}$, S. Lohrenz ${ }^{4}$, and C. Hopkinson ${ }^{5}$ \\ ${ }^{1}$ Dept. of Marine, Earth \& Atmospheric Sciences, North Carolina State University, Raleigh, NC 27695, USA \\ ${ }^{2}$ Dept. of Oceanography, Dalhousie University, Halifax, Canada \\ ${ }^{3}$ School of Marine Science and Policy, University of Delaware, Newark, DE 19716, USA \\ ${ }^{4}$ School for Marine Science and Technology, University of Massachusetts Dartmouth, New Bedford, MA 02747, USA \\ ${ }^{5}$ Dept. of Marine Sciences, University of Georgia, Athens, GA 30602, USA
}

Correspondence to: Z. Xue (zxue@ncsu.edu)

Received: 8 April 2013 - Published in Biogeosciences Discuss.: 8 May 2013

Revised: 15 September 2013 - Accepted: 27 September 2013 - Published: 12 November 2013

\begin{abstract}
A three-dimensional coupled physicalbiogeochemical model is applied to simulate and examine temporal and spatial variability of circulation and biogeochemical cycling in the Gulf of Mexico (GoM). The model is driven by realistic atmospheric forcing, open boundary conditions from a data assimilative global ocean circulation model, and observed freshwater and terrestrial nitrogen input from major rivers. A $7 \mathrm{yr}$ model hindcast (2004-2010) was performed, and validated against satellite observed sea surface height, surface chlorophyll, and in situ observations including coastal sea level, ocean temperature, salinity, and dissolved inorganic nitrogen (DIN) concentration. The model hindcast revealed clear seasonality in DIN, phytoplankton and zooplankton distributions in the GoM. An empirical orthogonal function analysis indicated a phaselocked pattern among DIN, phytoplankton and zooplankton concentrations. The GoM shelf nitrogen budget was also quantified, revealing that on an annual basis the DIN input is largely balanced by the removal through denitrification (an equivalent of $\sim 80 \%$ of DIN input) and offshore exports to the deep ocean (an equivalent of $\sim 17 \%$ of DIN input).
\end{abstract}

\section{Introduction}

Continental shelves are known to play an important role in global biogeochemical cycling (e.g., Liu et al., 2010) and are generally considered globally important sites of denitrification, importers of fixed nitrogen from the open ocean
(Seitzinger et al., 2006) and exporters of organic matter (Gattuso et al., 1998). The magnitude of organic and inorganic matter exchange between shelves and the open ocean is a key quantity, yet hard to determine empirically; thus estimates of these fluxes in coastal ocean/marginal seas are scarce.

The focus of this study is the Gulf of Mexico (GoM hereafter), which is the largest semi-enclosed marginal sea of the western Atlantic. Encompassing both eutrophic coastal waters and oligotrophic deep-ocean waters, it is a very productive marine ecosystem (estimated at $150-300 \mathrm{~g} \mathrm{C} \mathrm{m}^{-2} \mathrm{yr}^{-1}$; Heileman and Rabalais, 2008), and an important global reservoir of biodiversity and biomass of fish, sea birds and marine mammals. The upper ocean circulation in the GoM is dominated by the energetic Loop Current (LC hereafter), which is part of the North Atlantic western boundary current system. Large anticyclonic eddies aperiodically pinch off from the $\mathrm{LC}$ with an interval ranging from 3 to 17 months (Sturges and Leben, 2000). Associated with the LC and its eddies, are many smaller cyclonic and anticyclonic eddies. Confluence of along-shelf currents introduced by local wind stress and wind stress curl, together with interactions between eddies and shelf/slope circulation, can effectively transport highchlorophyll shelf waters into the deep GoM (e.g., MullerKarger et al., 1991; Toner et al., 2003; Zavala-Hidalgo et al., 2003). These transport processes therefore play a crucial role in changing temporal and spatial distributions of biogeochemical properties in the GoM, and subsequently the regional marine ecosystem dynamics. 
Previous marine biogeochemical studies in the GoM have been mainly based on satellite sea surface temperature and ocean color (surface chlorophyll) observations. Turbid and nutrient rich freshwater from major rivers and the associated high chlorophyll coastal waters have a strong impact on the coastal ocean color variability in the GoM (Muller-Karger et al., 1991; Gilbes et al., 1996; Jolliff et al., 2003; Toner et al., 2003; Martinez-Lopez and Zavala-Hidalgo, 2009; Nababan et al., 2011), especially in regions surrounding the Mississippi River delta, the shelf break off Veracruz, and the Bay of Campeche. Analyses of gulf-wide, long-term satellite sea surface Temperature (SST hereafter) and ocean color data provide evidence that the GoM waters have two characteristic states: (1) a winter mixing period characterized by annual maxima of surface pigment concentration, and (2) a thermally stratified period characterized by the annual minimum of surface pigment concentration (Jolliff et al., 2008). One major limitation of satellite data is that they are insufficient to determine marine ecosystem variations in the water column, and whether the spatial and temporal variability in surface pigment (e.g., chlorophyll) is caused by local biological effects or by three-dimensional ocean advection across large gradients. Because of the presence of relatively high concentrations of colored dissolved organic matter (CDOM), standard satellite data processing algorithms also tend to overestimate chlorophyll concentrations in the coastal regions (Nababan et al., 2011, also see observation/model data comparison in Sect. 3).

Ever-increasing human activities, such as shoreline development, changes in land use practices, and the resulting increases in pollutant and nutrient/carbon input continue to threaten the well-being of marine ecosystems in the GoM. Notable examples are coastal eutrophication, recurring hypoxia, a.k.a. the "dead zone" (e.g., Rabalais et al., 2002), and coastal ocean acidification (Cai et al., 2011) on the Louisiana-Texas shelf (LATEX hereafter). The Mississippi/Atchafalaya river system is the largest fluvial source in the GoM and delivers $0.11 \times 10^{9} \mathrm{~mol} \mathrm{yr}^{-1}$ (or 1.5 million ton $\mathrm{yr}^{-1}$ ) nitrogen into the LATEX shelf. This nitrogen load has tripled from the 1970s to 1990s (Goolsby et al, 2001). The primary production and $\mathrm{CO}_{2}$ uptake in the river plume has been found to be significantly correlated with increased inorganic nitrogen flux (e.g., Lohrenz et al., 1997; Guo et al., 2012). A classic explanation for the hypoxia on the LATEX shelf is that the nutrient-enhanced phytoplankton growth results in the sinking of enormous amounts of organic matter to bottom waters on the shelf. This organic matter is then decomposed microbially in the bottom water, drawing down the oxygen concentration and subsequently producing hypoxic conditions. Recent studies have shown that several other factors are also important in the formation of hypoxia (see Bianchi et al., 2010 for a detailed review). For example, Lehrter et al. (2009) reported that shelf-wide primary production was not significantly related to nutrient loading. Wiseman et al. (1997), CENR (2000), and Fennel et al. (2013) provide evidence that the physically controlled stratification is an important process regulating hypoxia formation below the pycnocline. DiMarco et al. (2010) pointed out that spatial variability of dissolved oxygen concentration is closely linked to local topographic features. These recent ideas urge more comprehensive studies of physical and biogeochemical processes affecting the GoM ecosystem.

Progress in ocean modeling has made it possible to apply coupled physical-biogeochemical models to realistically simulate and characterize marine ecosystem variations, and discover complex physical and biogeochemical interactions (e.g., Walsh et al., 1989). More recently, Fennel et al. (2011) successfully reproduced many features of observed nutrient and phytoplankton dynamics on the LATEX shelf covering the period of 1990-2004. Model results showed a positive correlation between phytoplankton biomass and nitrogen loading. However, simulated phytoplankton growth rate was not correlated with nitrogen loading, suggesting that the changes in biomass may be controlled by loss processes (e.g., vertical sinking, mortality, grazing by zooplankton) as well. Fennel et al. (2013) further incorporated dissolved oxygen concentration into the coupled model and results supported the view that simulated hypoxia spatial extent is very sensitive to the parameterization of sediment oxygen consumption and vertical stratification.

Here we present a coupled physical-biogeochemical modeling study of ocean circulation and biochemical cycling for the entire GoM. Complementary to the Fennel et al. (2011) study, our work is aimed at achieving an improved understanding of marine ecosystem variations and their relations with three-dimensional ocean circulation in a gulf-wide context. Our specific objectives were to (1) investigate temporal and spatial variability of ocean circulation and marine ecosystem dynamics in the GoM, and (2) to quantify the nitrogen budget of the GoM shelf.

\section{Methods}

\subsection{Physical model}

The circulation hindcast model was implemented based on the Regional Ocean Modeling System (ROMS, Haidvogel et al. 2008; Shchepetkin and McWilliams, 2005). The model domain (Fig. 1) encompasses the entire Gulf of Mexico and South Atlantic Bight, hereafter SABGOM ROMS. Details of this model implementation are given in Hyun and $\mathrm{He}$ (2010). Briefly, the model has a horizontal resolution of $5 \mathrm{~km}$. Vertically, there are 36 terrain-following layers weighted to better resolve surface and bottom boundary layers. For open boundary conditions, SABGOM ROMS is one-way nested inside the $1 / 12^{\circ}$ data assimilative North Atlantic Hybrid Coordinate Ocean Model (HYCOM/NCODA, Chassignet et al., 2003). Open boundary conditions of water mass and baroclinic velocity were specified following the method of Marchesiello et 
al. (2001), whereby Orlanski-type radiation conditions were used in conjunction with relaxation to HYCOM/NCODA solutions. Free surface and depth-averaged velocity boundary conditions were specified using the method of Flather (1976) with the external subtidal information defined by HYCOM/NCODA plus eight tidal constituents (Q1, O1, P1, $\mathrm{K} 1, \mathrm{~N} 2, \mathrm{M} 2, \mathrm{~S} 2, \mathrm{~K} 2$ ) derived from OTIS regional tidal solution (Egbert and Erofeeva, 2002). For both meteorological momentum and buoyancy forcing, we utilized 3-hourly, $32 \mathrm{~km}$ horizontal resolution North American Regional Reanalysis data (NARR, http://www.esrl.noaa.gov/psd/). The Mellor and Yamada (1982) Level 2.5 closure scheme was applied to compute the vertical turbulent mixing, as well as the quadratic drag formulation for the bottom friction specification.

\subsection{Biogeochemical model}

The SABGOM ROMS ocean circulation model is coupled with a marine biogeochemical model described in Fennel et al. $(2006,2008,2011)$. While this biogeochemical model is capable of simulating phosphate and the inorganic carbon processes in addition to nitrogen cycling, we focused on the nitrogen cycle first in this work. Omission of phosphate cycling is justified by results of earlier studies (e.g., Rabalais et al., 2002) that have shown that the primary production on the LATEX shelf is typically nitrogen-limited during the low discharge season, and that dissolved $\mathrm{NO}_{\mathrm{x}}: \mathrm{PO}_{4}$ ratios are often higher than the 16:1 "Redfield ratio" (Lohrenz et al., 2008; Lohrenz et al., 1997; Lohrenz et al., 1999). An understanding of the role of phosphate and how its rapid recycling affects regional marine ecosystem processes warrants more detailed study (e.g., Laurent et al., 2012 for the LATEX shelf). However, here we focus on nitrogen and will report on the role of phosphate in a future correspondence.

The nitrogen cycling model has seven state variables: two species of dissolved inorganic nitrogen (DIN hereafter, nitrate $\left(\mathrm{NO}_{3}\right)$ and ammonium $\left(\mathrm{NH}_{4}\right)$ ), one functional phytoplankton group, chlorophyll as a separate state variable to allow for photoacclimation, one functional zooplankton group, and two pools of detritus representing large, fast-sinking particles, and suspended, small particles. The sediment component of the biogeochemical model is a simplified representation of benthic remineralization processes, where the flux of sinking organic matter out of the bottommost grid box results immediately in a corresponding influx of ammonium at the sediment-water interface. The parameterization accounts for the loss of fixed nitrogen through sediment denitrification based on the linear relationship between sediment oxygen consumption and denitrification reported by Seitzinger and Giblin (1996) and only accounts for the portion of denitrification that is supported by nitrification of ammonium in the sediment (referred to as coupled nitrificationdenitrification).
Freshwater and nitrogen input from 63 major rivers (38 in the United States, 23 in Mexico, and 2 in Cuba) along the gulf coast and South Atlantic Bight were included in the coupled model simulation. For rivers located inside the United States, daily riverine fresh water discharge and DIN flux values were retrieved from the US Geological Survey river gauges (e.g., Aulenbach et al., 2007). Such riverine data were not available for Mexican and Cuban rivers however. Instead we utilized the long-term estimation or climatological means developed by Milliman and Farnsworth (2011), Fluentes-Yaco et al. (2001), and Nixon (1996). For the Mississippi and Atchafalaya rivers in particular, we also considered riverine particulate organic nitrogen (PON hereafter) export, which was determined as the difference between total unfiltered Kjeldahl nitrogen and $\mathrm{NH}_{4}$ (Fennel et al., 2011). The PON flux for other rivers was assigned a small, positive value as no continuous Kjeldahl nitrogen observation was available.

Similar to the LATEX model simulation reported by Fennel et al. (2011), we specified SABGOM initial and boundary conditions of $\mathrm{NO}_{3}$ using World Ocean Atlas data (Garcia et al., 2010). Other variables $\left(\mathrm{NH}_{4}\right.$, phytoplankton, chlorophyll, zooplankton, small and large particles) were initialized with small, positive values over the entire domain. Biogeochemical model parameters (i.e., phytoplankton growth/loss rates, remineralization and light attenuation) were chosen as those used in Fennel et al. (2006, 2011).

We performed a 7 yr (1 January 2004-31 December 2010) regional ocean circulation and marine ecosystem hindcast. The first year was used to spin up the biogeochemical model. Analyses described in the following sections focus on the next 6 yr period between 1 January 2005 and 31 December 2010.

One of the analyses to be discussed later in the text involves quantifying along-shelf and cross-shelf exchange of water and nitrogen (DIN and PON). Compared with horizontal advection, diffusion plays only a minor role in nutrient exchanges in the open ocean (Fasham et al., 1993; McGillicuddy et al., 2003). Considering this, the cross-shelf and along-shelf exchange was estimated using the mean velocity and DIN/PON concentration fields (averaged internally through all steps within a month) of the 72 months during 2005-2010. We first decomposed the model simulated velocity fields into along and across $50 \mathrm{~m}$ isobath directions, then the cross-shelf and along-shelf nitrogen fluxes were calculated according to the equations below:

$$
\begin{aligned}
& E_{\mathrm{h}}=\int_{-50}^{0} U_{\mathrm{h}}(z) \times N(z) \cdot \mathrm{d} z \text { where } U_{\mathrm{h}}=\operatorname{proj}_{\Delta \mathrm{h}} U, \\
& E_{\mathrm{t}}=\int_{-50}^{0} U_{\mathrm{t}}(z) \times N(z) \cdot \mathrm{d} z \text { where } U_{\mathrm{t}}=\operatorname{proj}_{\Delta \mathrm{t}} U .
\end{aligned}
$$




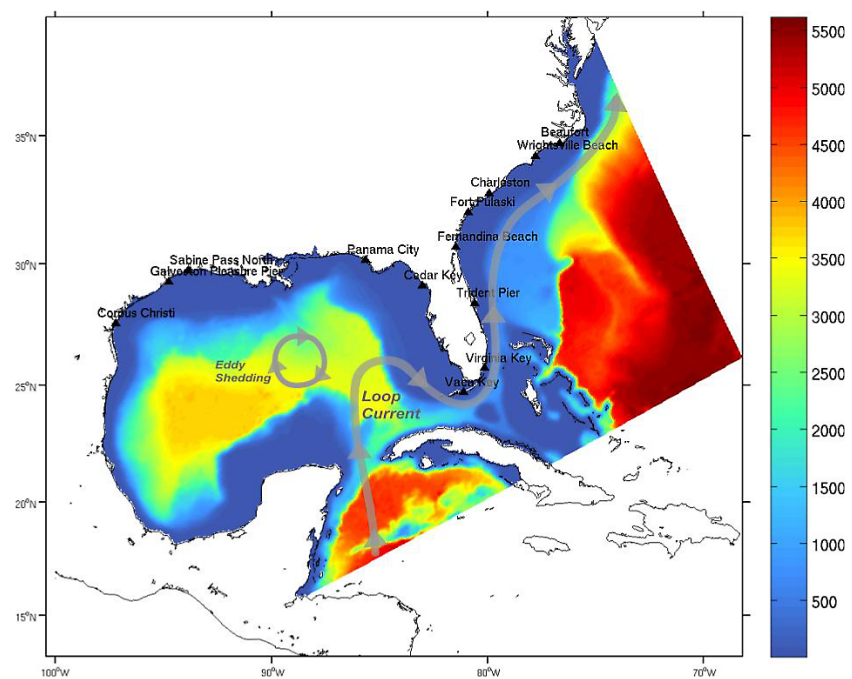

Fig. 1. The SABGOM ROMS model domain overlaid with water depth (color-shading), location of 13 tidal stations (black triangles), and a schematic circulation pattern.

Here $E_{\mathrm{h}}$ and $E_{\mathrm{t}}$ are the nitrogen transport fluxes (unit: mmol N s${ }^{-1} \mathrm{~m}^{-1}$ ) across and along isobaths, respectively, $U_{\mathrm{h}}$ and $U_{\mathrm{t}}$ are the normal and tangential components of the velocity along the isobath (unit: $\mathrm{m} \mathrm{s}^{-1}$ ), respectively, $N$ is the DIN $\left(\mathrm{NO}_{3}\right.$ and $\mathrm{NH}_{4}$ combined) and PON (phytoplankton, zooplankton, and small and large detritus combined) concentration at a given depth (unit: $\mathrm{mmol} \mathrm{N} \mathrm{m}^{-3}$ ), and $z$ is water depth (unit: $m$ ).

\section{Model-data comparisons}

Model-simulated physical and biogeochemical variables were validated against extensive satellite and in situ observations (see Figs. 1 and 2 for positions of coastal sea level stations and ship surveys). Hourly coastal sea level observations were obtained from 13 tidal gauges operated by the NOAA National Ocean Service/Center for Operational Oceanographic Products and Services (NOS/CO-OPS). We were especially interested in the model skill in resolving subtidal circulation processes because they dominate material property transport in the ocean. As such, a $36 \mathrm{~h}$ low pass filter was applied to both observed and modeled sea level time series to facilitate comparisons. An example of this can be seen in Fig. 3, which shows the comparisons between observed and modeled subtidal sea levels in 2008 at Charleston, Fernandina Beach, Galveston, and Corpus Christi. At all these locations, the modeled sea level time series track their observational counterparts reasonably well. Both the seasonal trend and synoptic storm surge events (as results of hurricanes) are well reproduced. A more robust statistical assessment of the model skill over the entire $7 \mathrm{yr}$ hindcast period is shown in the form of a Taylor diagram (Fig. 4; Taylor, 2001),

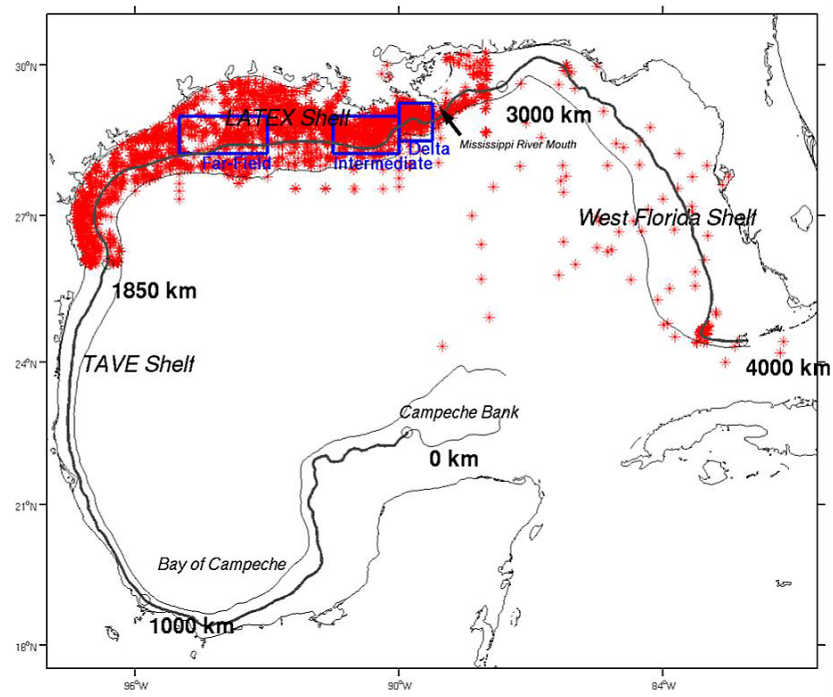

Fig. 2. Locations (star) of in situ ship survey data. Also shown are the 50 and $200 \mathrm{~m}$ isobaths in the Gulf of Mexico, and the location of three subregions: Delta, Intermediate, and Far-field. Using the $50 \mathrm{~m}$ isobath as the boundary between the inner shelf and deep ocean $(\sim 4000 \mathrm{~km}$ long $)$, we divide the shelf areas in the gulf into 4 major sections (see Fig. 2): (1) the Bay of Campeche shelf (bounded by the $50 \mathrm{~m}$ isobath between 0 and $1000 \mathrm{~km}$ starting from the Campeche Bank, (2) the Tamaulipas-Veracruz shelf (bounded by the $50 \mathrm{~m}$ isobath between 1000 and $1850 \mathrm{~km}$ ), (3) the LATEX shelf (bounded by the $50 \mathrm{~m}$ isobath between 1850 and $3000 \mathrm{~km}$ ), and (4) the West Florida Shelf (bounded by the $50 \mathrm{~m}$ isobath between 3000 and $4000 \mathrm{~km}$ ).

where correlation coefficients, centered root mean square difference (RMSD) between observed and simulated subtidal sea level, and their normalized standard deviations are all present in a single plot. At most of the 13 coastal stations mentioned above, the correlation coefficients between simulated and observed sea level range between 0.7 and 0.95 , and the simulated sea levels are within one standard deviation of the observed values.

In a gulf-wide spatial context, we compared eddy kinetic energy (EKE hereafter) derived from satellite altimetry observations (AVISO sea surface height) with model-simulated EKE. Reasonably good agreement was found between the satellite- and model-derived multiyear mean (2004-2010) EKE (Fig. 5), an indication that the model is capable of reproducing gulf-wide sea-level and associated circulation and EKE distributions. It is not surprising to see that high EKE values were associated with the LC and its adjacent eddies in the GoM while the shelf regions (e.g., west Florida shelf, LATEX shelf) generally had low EKE.

We also took advantage of extensive in situ observations (shipboard CTD casts and Niskin bottle samplings) collected during research cruises in the northern GoM spanning over the period of 2005-2010 (Data were collected from different sources, including the Environmental Protection Agency; 

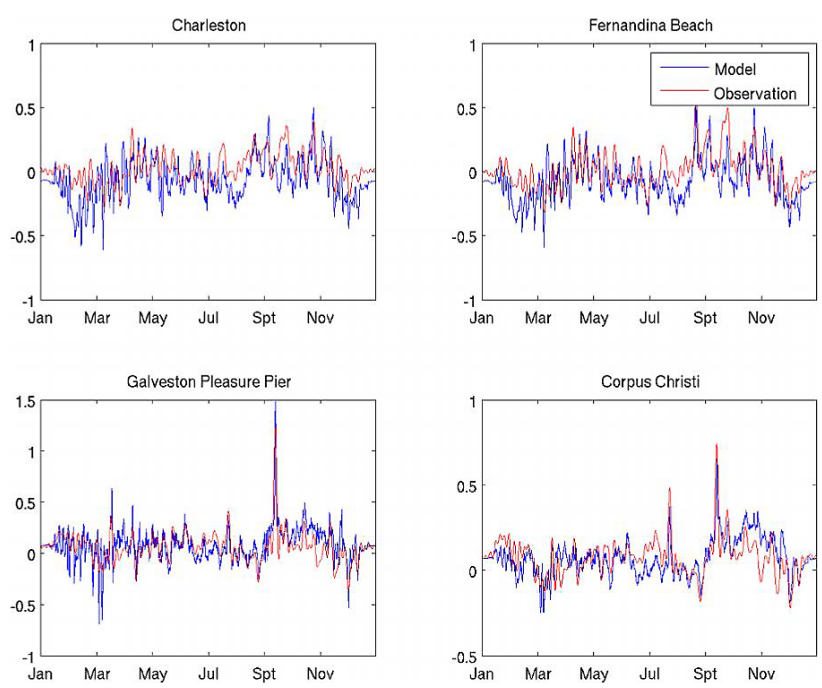

Fig. 3. Comparisons between observed and simulated sea-level time series at four tidal stations in 2008.

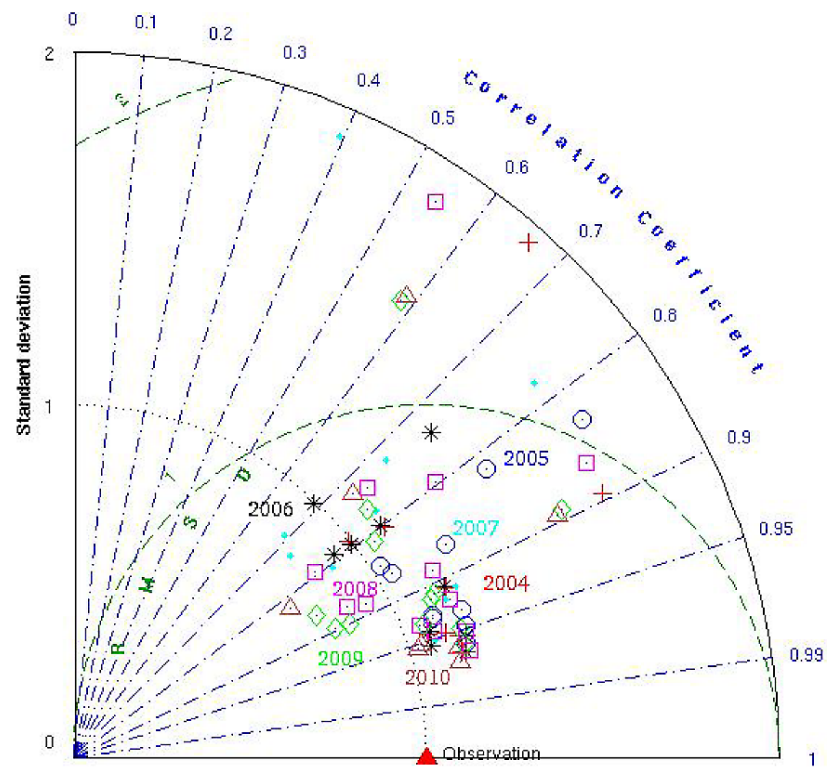

Fig. 4. Taylor diagram for model simulated and observed sea-level anomaly at 13 tidal stations from 2004 to 2010. Radial distance represents the ratio of simulated to observed standard deviations, and azimuthal angle represents model-data correlation. Green arcs represent centered root mean square difference between model and data.

Lehrter et al., 2009, 2012; Lohrenz et al., 2008; Cai et al., 2011; Huang et al., 2012; Louisiana Universities Marine Consortium; Rabalais et al., 2007; Mechanisms Controlling Hypoxia (MCH) Project; Southeast Monitoring and Assessment Program (SEAMAP); the NSF-funded GulfCarbon Project and Mississippi-Atchafalaya-Gulf of Mexico Mixing Experiment (MMAGMIX)). Together, there are more than 8000 surface observations of water temperature, salin-
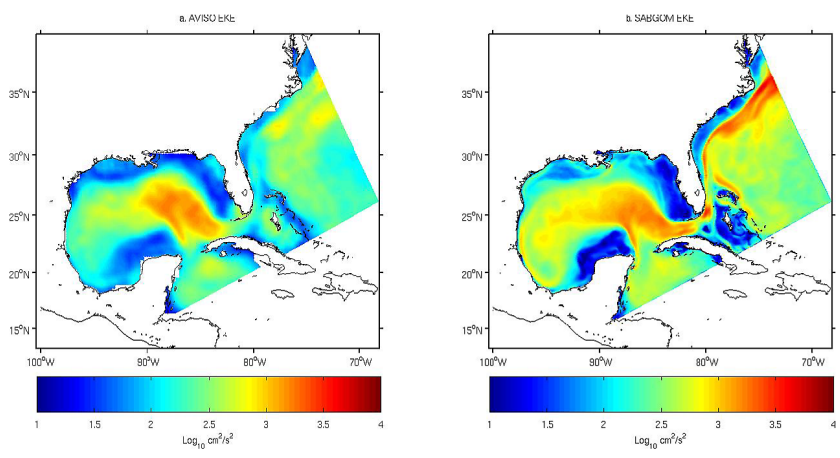

Fig. 5. Comparison of 7 yr (2004-2010) mean eddy kinetic energy calculated based on (a) AVISO SSH observation and (b) SABGOM model simulated SSH.

ity, $\mathrm{NO}_{3}, \mathrm{NH}_{4}$, and chlorophyll concentrations. To avoid the scale mismatch between in situ point measurements and our $5 \mathrm{~km}$ model grid resolution, we followed the approach used in Fennel et al. (2011), and divided the northern gulf area into three subregions (i.e., Delta, Intermediate, and Far-field, see Fig. 2). Observed and modeled (both are surface values unless otherwise stated) variables that fell into each subregion were spatially averaged. The resulting time series comparisons were used to evaluate the model's skill in predicting each state variable under consideration. Figures 6 and 7 show the comparisons between observed and simulated sea surface salinity (Fig. 6a), surface temperature (Fig. 6b), $\mathrm{NO}_{3}$ (Fig. 7a), and chlorophyll concentration (Fig. 7b). For chlorophyll, we also acquired Moderate Resolution Imaging Spectroradiometer (MODIS hereafter) satellite-derived monthly mean time series for the comparison in each of the three subregions. The model reproduced both seasonal and interannual variations of salinity, temperature, $\mathrm{NO}_{3}$, and chlorophyll concentration reasonably well. Simulated values generally fell within the 1 standard deviation range of corresponding observations. Surface temperature and salinity in all three subregions were characterized by clear seasonal cycles. We note that the model underpredicted a sharp salinity drop in spring-summer 2008, which was induced by the Mississippi River flooding during that year (White, el al., 2009; also see freshwater discharge time series in Fig. 9a). This was likely due to small-scale variability in the MississippiAtchafalaya river plume structure that was not fully resolved by our $5 \mathrm{~km}$ resolution model.

Seasonal patterns of $\mathrm{NO}_{3}$ and chlorophyll concentrations were similar. In general, these variables peaked in late spring-early summer (April-July) when riverine discharge was highest. The influence of river discharge and $\mathrm{NO}_{3}$ input on regional hydrography decreased rapidly with increasing distance from the delta. It was encouraging to see that model-simulated surface chlorophyll fields were in general agreement with those observed in situ (Fig. 7b). Surface chlorophyll observed by MODIS exhibited similar temporal 

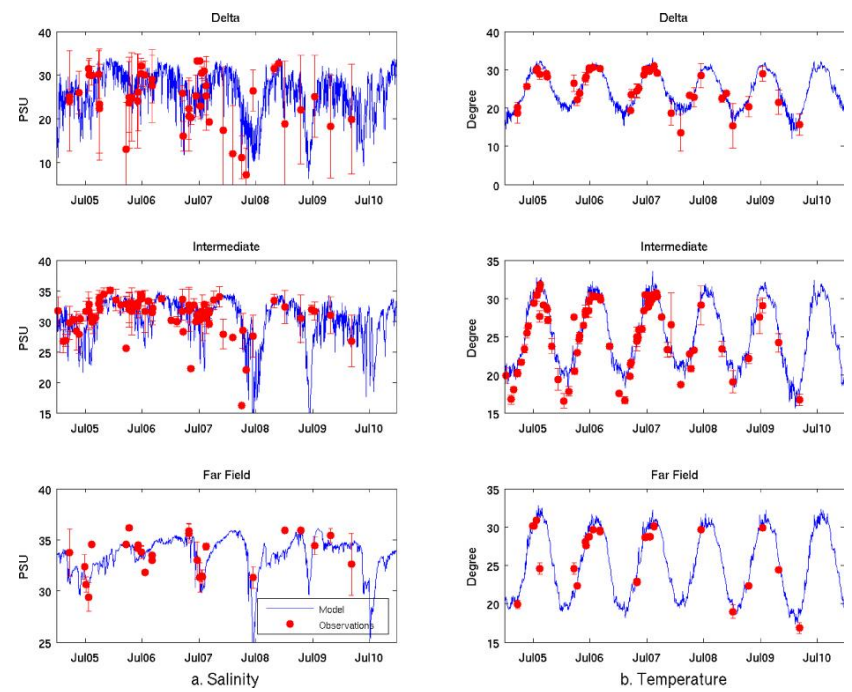

Fig. 6. Time series comparisons between observed and simulated (a) sea surface salinity (left panels) and (b) sea surface temperature (right panels) in 2005-2010. Results are presented for each of three subregions illustrated in Fig. 2. Blue lines are simulated values and filled red circles are observed values. Error bars stand for one standard deviation of available observations.

variations, but generally overestimated the concentrations measured in situ. This was not surprising because MODIS estimates of chlorophyll were likely influenced by other optical constituents including suspended sediment and CDOM (e.g., Nababan et al., 2011). Nevertheless, MODIS imagery provided valuable information about the spatial distribution of surface chlorophyll, allowing the examination of model skill over the entire gulf, as can been seen for the comparison of seasonal means of observed and simulated surface chlorophyll fields (Fig. 8). These means were calculated by averaging MODIS-derived and model-simulated chlorophyll concentration, respectively over a $6 \mathrm{yr}$ period (2005-2010). The spatial correlation coefficients between the two were 0.60 , $0.65,0.53$ and 0.45 for spring, summer, fall, and winter, respectively, suggesting that the model has intrinsic capability to reproduce the temporal and spatial variations of surface chlorophyll. Both MODIS data and model simulation show that high chlorophyll concentrations were present in coastal areas adjacent to major rivers, such as the LATEX shelf, the Bay of Campeche and Campeche Bank. The chlorophyll content was much lower in the deep ocean. In general, the surface chlorophyll concentration was higher in winter and spring than in summer and fall.

In summary, all the above-mentioned comparisons (Figs. 3-8) indicate that our coupled physicalbiogeochemical model is capable of resolving the main spatiotemporal variations of circulation and biogeochemical variables in the GoM, providing confidence in our approach to use the $7 \mathrm{yr}$ hindcast to further characterize the temporal
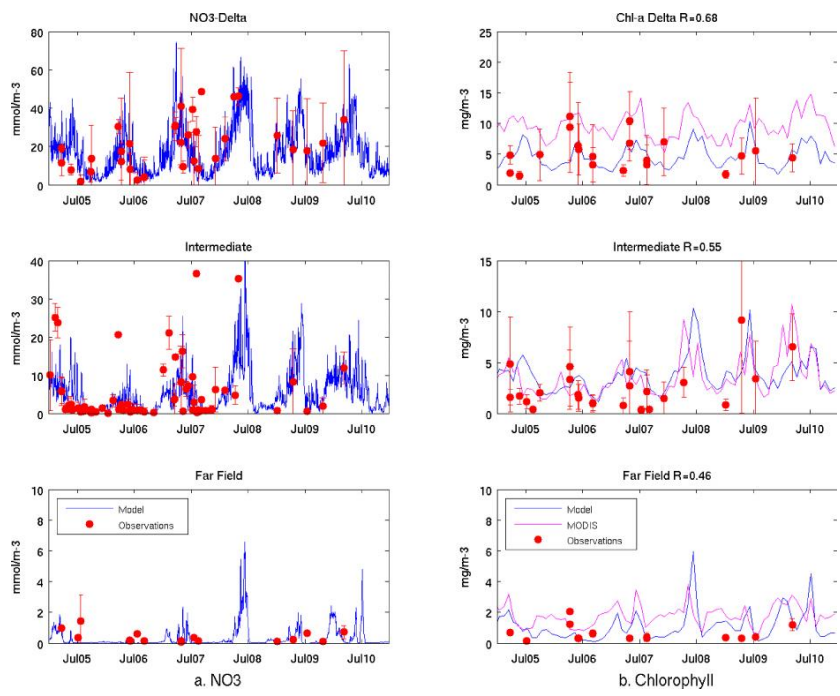

Fig. 7. Time series comparison between observed and simulated (similar to Fig. 6) (a) nitrate (left panel) and (b) chlorophyll (right panels). For chlorophyll comparison, MODIS monthly mean pigment concentration data (pink line) are also shown for each of three regions.

and spatial variability of physical and biogeochemical dynamics over the entire gulf.

\section{Results and discussion}

\subsection{Nutrient, phytoplankton, and zooplankton dynamics}

The Mississippi-Atchafalaya river system provides the majority of the nutrient loading on the LATEX shelf (Walsh et al., 1989; Turner and Rabalais, 1999). In our 7 yr simulation, we found riverine DIN input on the LATEX shelf accounts for $\sim 80 \%$ of the total DIN loading in the GoM (108.86 and $135.87 \times 10^{9} \mathrm{~mol} \mathrm{~N} \mathrm{yr}^{-1}$, Table 2$)$. We first examine the correlations among riverine input and DIN, phytoplankton, and zooplankton concentrations on the LATEX shelf. We note that our simulation spans 2004-2010. It partially overlaps with the modeling period (1990-2004) of Fennel et al. (2011), allowing some comparisons to be drawn between the two studies.

Concentrations of DIN, phytoplankton and zooplankton (surface values, unless otherwise stated) were spatially averaged for each of the three subregions on the LATEX shelf. The resulting time series were then temporally averaged to come up with monthly mean values. Clear seasonality could be seen in monthly mean riverine nutrient input as well as in the monthly averaged DIN, phytoplankton, and zooplankton concentration on the LATEX shelf (Fig. 9). The maximum riverine DIN input occurred in May, preceding the coastal DIN, phytoplankton and zooplankton peaks by one month to 

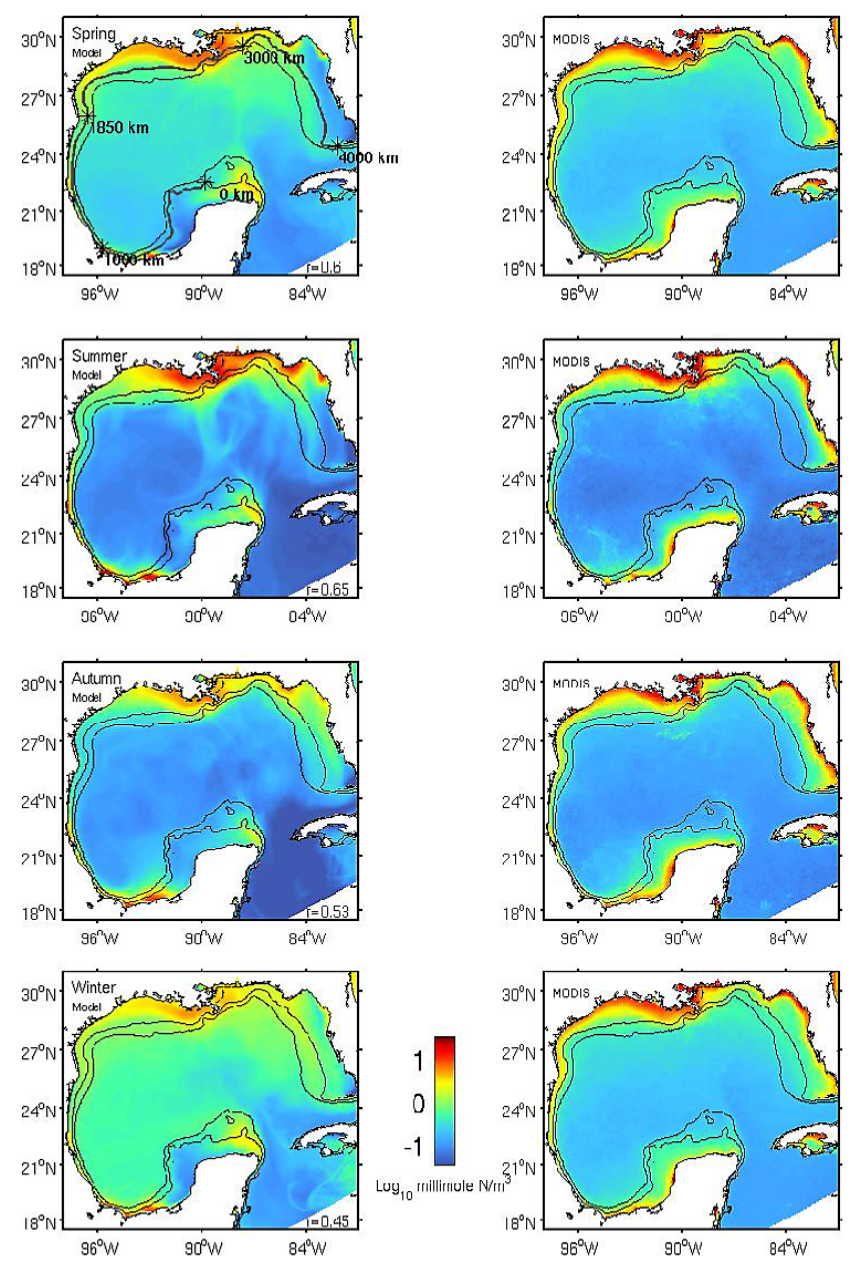

Fig. 8. Comparison of simulated (left panels) and MODIS observed (right panels) seasonal mean surface chlorophyll. Also shown in each panel are 50 (labeled with distance) and $200 \mathrm{~m}$ isobaths.

two months. DIN, phytoplankton and zooplankton concentrations were characterized by a clear decreasing trend from Delta to Intermediate, and further to the Far-field region. The correlation coefficient between the riverine input and coastal DIN concentration time series was 0.85 for the Delta, 0.67 for the Intermediate regions, and 0.27 for the Far-field region. The significant reduction in correlation in the Far-field region was consistent with the findings of Lehrter et al. (2009), who reported that there was no clear relationship between Mississippi River nutrient loading and regional-wide primary production on the LATEX shelf.

The influence of river plumes is typically limited to the inner-mid shelf $(<50 \mathrm{~m}$ water depth) in the GoM (e.g., Morey et al., 2003). Both satellite-derived and modelsimulated surface chlorophyll maps (Fig. 8) are consistent with the presence of high chlorophyll concentration mainly located near the coast. In the following section, we separate the gulf into shelf and deep-ocean regions using the $50 \mathrm{~m}$ isobath as the demarcation line. We consider the temporal
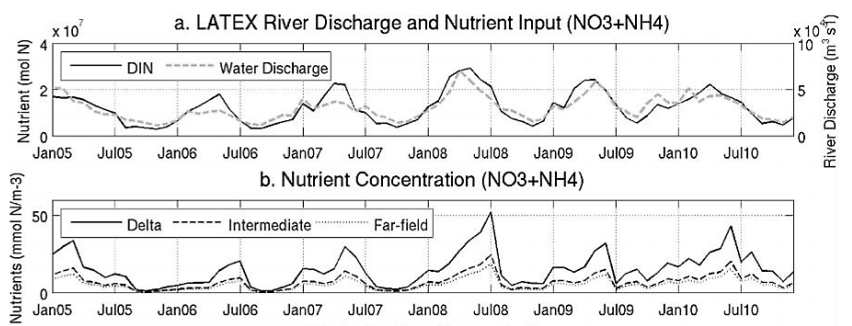

c. Phytoplankton Concentration
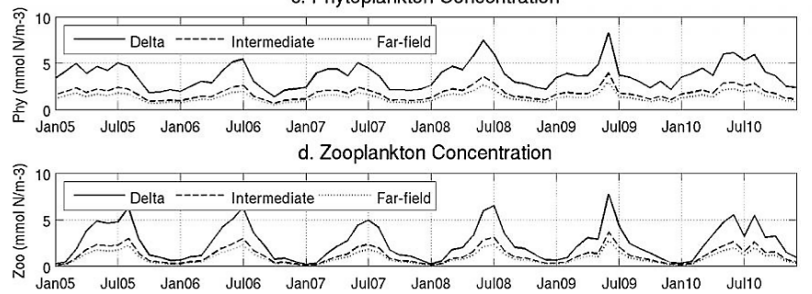

Fig. 9. Monthly mean time series of (a) river discharge and DIN loading, (b) surface DIN concentration, (c) surface phytoplankton concentration, and (d) surface zooplankton concentration in each of the three analysis regions (Delta, Intermediate, Far-field) on the LATEX shelf.

variations of DIN, phytoplankton, and zooplankton concentrations in each region and their dominant modes of variability.

Consistent with what we found on the LATEX shelf, DIN, phytoplankton and zooplankton concentrations in the GoM shelves are strongly correlated with coastal river input (Fig. 10a, correlation coefficient: 0.91). The maximum riverine freshwater and DIN input was seen in July 2008 (largely contributed by the 2008 Mississippi River flooding), along with high DIN, phytoplankton and zooplankton concentrations on the shelf. Surface DIN concentrations in the deep ocean were limited (to $\sim 1 / 10$ of the inner shelf) and showed no clear correlation with riverine input. The only exception to this was in summer 2008 when DIN values peaked in association with the flooding of Mississippi River, which increased DIN loading and contributed to higher DIN concentrations offshore. Unlike on the shelf, DIN concentrations in the deep ocean were seen to increase around January when wind mixing was stronger (Jolliff et al., 2008). A high DIN peak appeared around February 2010, which was also observed during a March 2010 cruise and was related to wind-driven transport of the plume to normally oligotrophic offshore waters (Huang et al., in press). Because of the enhanced biological activity as a result of plume transport, an unusually high $\mathrm{CO}_{2}$ sink was also observed during that cruise. Surface phytoplankton concentrations in the deep ocean were $\sim 0.5 \mathrm{mmol} \mathrm{N} \mathrm{m}^{-3}$, about $50 \%$ of that on the shelf (Fig. 10b), and lagged the temporal variations in DIN by $\sim$ one month (Fig. 10c). Zooplankton concentrations in the deep ocean were $\sim 0.01 \mathrm{mmol} \mathrm{N} \mathrm{m}^{-3}$, about $20 \%$ of that on the shelf (Fig. 10d). 

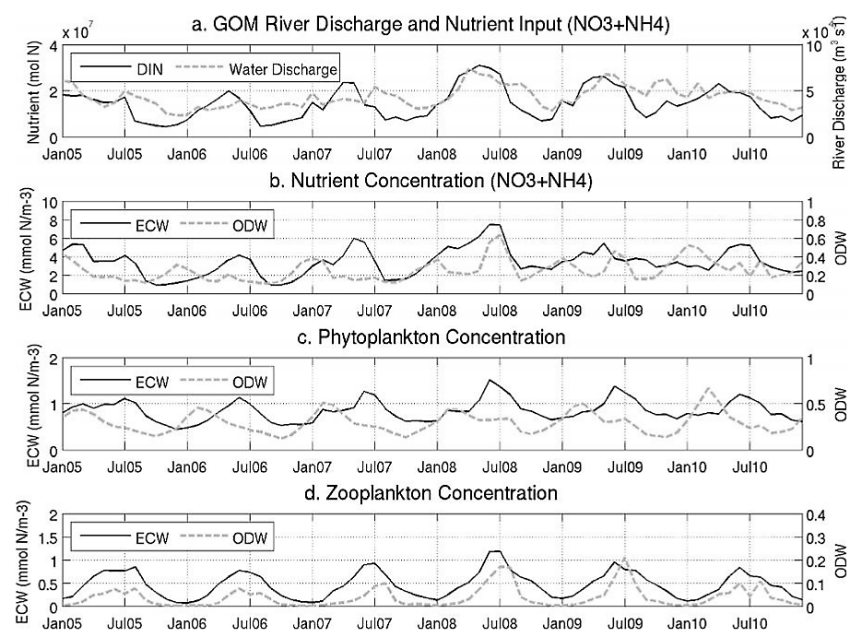

Fig. 10. Monthly mean time series of (a) river discharge and DIN loading, (b) surface DIN concentration, (c) surface phytoplankton concentration, and (d) surface zooplankton concentration on the shelf, and deep-sea areas over the entire gulf.

To quantify the intrinsic linkages between DIN, phytoplankton and zooplankton variability, we removed their multiyear mean (2005-2010) and applied an empirical orthogonal function (EOF) analysis to their residuals. The temporal mean DIN and phytoplankton fields resembled each other, both showing high values on the shelf (Fig. 11, upper panels). The mean zooplankton concentrations were elevated in the northern GoM. The first EOF mode of the DIN, phytoplankton, and zooplankton accounted for 76, 50, and $80 \%$ of their respective variance. Their corresponding first principal components (PC1s) displayed clear seasonal cycles. DIN, phytoplankton, and zooplankton concentrations each reached their peak values in May-June, June, June-July, respectively. Together, surface DIN, phytoplankton and zooplankton concentrations showed a phase-locked pattern. The DIN variations generally lead phytoplankton variations by $0-1$ month, which in turn lead zooplankton variations by $0-1$ month. The second EOF modes of DIN, phytoplankton, and zooplankton accounted for 19,34 , and $14 \%$ of their respective variances, representing other higher order dynamical processes.

\subsection{Shelf nitrogen budget}

Monthly means (averaged over 2005-2010) of simulated cross-shelf (normal components) velocity and nitrogen flux at the $50 \mathrm{~m}$ isobath in the gulf exhibited distinct temporal patterns (Fig. 12). Although the depth integrated current shows significant variability along the $50 \mathrm{~m}$ isobath, both DIN and PON fluxes were dominated by an overall offshore transport (from shelf to deep ocean; Fig. 12b-d). Compared with DIN, the monthly climatology of the PON flux was more similar to the cross-shelf current climatology. This may be explained by the observation that transport of PON

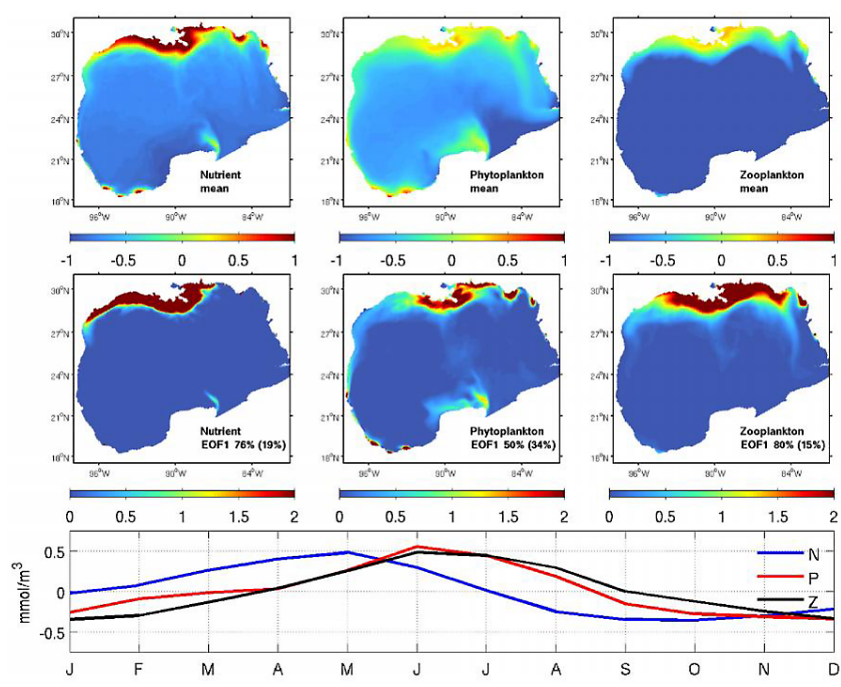

Fig. 11. EOF analyses of surface DIN, phytoplankton and zooplankton fields. Mean fields are shown in the top panels (units: mmol $\mathrm{N} \mathrm{m}^{-3}$, log scale), the first EOF modes and the variance they account for are shown in the middle panels and their corresponding first principle components are shown in the bottom panels.

was predominantly associated with surface waters, making PON transport more sensitive to surface wind and current forcing; in contrast, the higher DIN concentrations in deep water resulted in DIN transport being more strongly influenced by deep water movements. A similar nitrogen transport pattern has also been reported in the Middle Atlantic Bight (Fennel et al., 2006). Along the $50 \mathrm{~m}$ isobath, substantial cross-shelf nitrogen exchange was found to the southeast of the Mississippi River mouth. Overall the shelf waters receive $135.87 \times 10^{9} \mathrm{molDIN} \mathrm{yr}^{-1}$ from rivers (estimated by river nitrogen concentration $\times$ freshwater discharge $\times$ time), and export $24.93 \times 10^{9} \mathrm{molN}\left(10.49 \times 10^{9} \mathrm{~mol} \mathrm{DIN}\right.$ and $14.44 \times 10^{9} \mathrm{~mol}$ PON) to the deep ocean (see: Tables 1 and 2).

The factors that determine water transport and nitrogen fluxes in the gulf can be explored by examining the shelf circulation and wind forcing on a region-by-region basis. To do that we generated seasonal means of surface wind and surface currents by averaging our 6 yr (2005-2010) model hindcast solutions. We found that the surface wind shows a similar spatial and temporal pattern with the COADS wind climatology (DaSilva et al., 1994). Shelf circulation is mainly wind-driven and the circulation pattern is generally consistent with a previous GoM modeling study covering the period of 1994-2004 by Morey et al. (2005).

Using the $50 \mathrm{~m}$ isobath as the boundary between the inner shelf and deep ocean, we can divide the shelf areas in the Gulf into 4 major sections (see Fig. 2): (1) the Bay of Campeche shelf (BOC) hereafter, bounded by the $50 \mathrm{~m}$ isobath between 0 and $1000 \mathrm{~km}$ starting from the Campeche Bank, Fig. 13), (2) the Tamaulipas-Veracruz shelf (TAVE 
Table 1. River, cross-shelf (at $50 \mathrm{~m}$ isobath), along-shelf, and denitrification flux in the inner shelf.

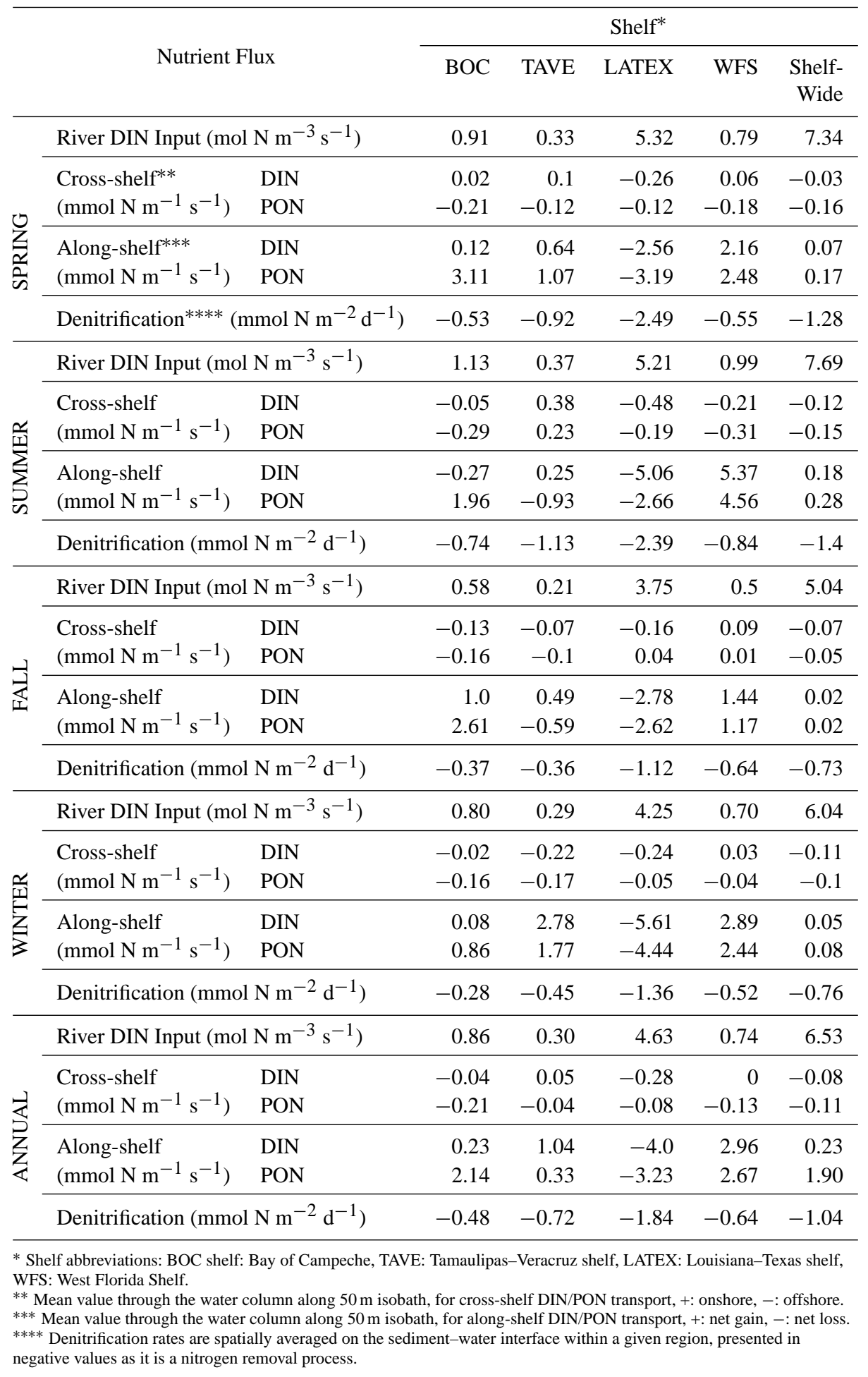

shelf hereafter, bounded by the $50 \mathrm{~m}$ isobath between 1000 and $1850 \mathrm{~km}$, Fig. 14), (3) the LATEX shelf (bounded by the $50 \mathrm{~m}$ isobath between 1850 and $3000 \mathrm{~km}$, Fig. 15), and (4) the West Florida Shelf (WFS hereafter, bounded by the
$50 \mathrm{~m}$ isobath between 3000 and $4000 \mathrm{~km}$, Fig. 16). Within each section, the nitrogen flux between the shelf waters and deep-ocean (cross-shelf) as well as between different sections (along-shelf) can be assessed in conjunction with local 
Table 2. River, cross-shelf (at $50 \mathrm{~m}$ isobath), along-shelf, and denitrification budget in the inner shelf.

\begin{tabular}{|c|c|c|c|c|c|c|c|}
\hline & & & & & Shelf* & & \\
\hline & utrient Budget (10 & $\left.\mathrm{mol} \mathrm{N} \mathrm{yr}^{-1}\right)$ & BOC & TAVE & LATEX & WFS & Shelf- \\
\hline & River DIN Input & & 1.41 & 0.26 & 42.68 & 2.08 & 46.42 \\
\hline & & DIN & 0.14 & 0.66 & -2.32 & 0.5 & -1.02 \\
\hline & Cro & PON & -1.68 & -0.8 & -1.05 & -1.39 & -4.93 \\
\hline 光 & Along_shelf*** & DIN & 0.32 & 0.25 & -2.15 & 1.87 & 0.29 \\
\hline & Along-snell & PON & 3.06 & 0.44 & -2.64 & 2.12 & 2.98 \\
\hline & Denitrification $^{* *}$ & & -3.56 & -2.0 & -24.93 & -5.28 & -35.77 \\
\hline & River DIN Input & & 4.30 & 0.59 & 26.31 & 7.27 & 38.47 \\
\hline & & DIN & -0.37 & 2.52 & -4.28 & -1.63 & -3.77 \\
\hline 舀 & Cross-snelt & PON & -2.24 & 1.55 & -1.69 & -2.46 & -4.85 \\
\hline$\sum_{j}$ & Along-shelf & DIN & 0.25 & -0.19 & -4.5 & 4.67 & 0.23 \\
\hline 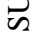 & Aiong-snent & PON & 2.58 & -1.2 & -2.81 & 3.91 & 2.48 \\
\hline & Denitrification & & -4.97 & -2.46 & -23.87 & -7.97 & -39.27 \\
\hline & River DIN Input & & 4.19 & 0.59 & 13.85 & 2.54 & 21.17 \\
\hline & & DIN & -0.98 & -0.45 & -1.44 & 0.72 & -2.15 \\
\hline 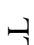 & Cross-shelt & PON & -1.23 & -0.64 & 0.36 & 0.07 & -1.43 \\
\hline I & Along-shelf & DIN & 0.2 & 0.79 & -2.12 & 1.25 & 0.12 \\
\hline & Along-snelf & PON & 0.65 & 0.78 & -1.95 & 1.01 & 0.49 \\
\hline & Denitrification & & -2.47 & -0.79 & -11.24 & -6.08 & 20.59 \\
\hline & River DIN Input & & 2.52 & 0.39 & 26.02 & 0.88 & 29.81 \\
\hline & Cross $>$ & DIN & -0.18 & -1.45 & -2.19 & 0.27 & -3.55 \\
\hline$\frac{\alpha}{I I}$ & Cross-snelt & PON & -1.28 & -1.15 & -0.49 & -0.31 & -3.23 \\
\hline $\bar{Z}$ & Along-shelf & DIN & 0.2 & 1.68 & -4.28 & 2.45 & 0.05 \\
\hline 3 & Along-shelf & PON & 0.74 & 1.14 & -3.46 & 1.98 & 0.4 \\
\hline & Denitrification & & -1.86 & -0.99 & -13.61 & -4.94 & -21.4 \\
\hline & River DIN Input & & 12.42 & 1.83 & 108.86 & 12.76 & 135.87 \\
\hline & $\operatorname{Cros}$ & DIN & -1.4 & 1.28 & -10.23 & -0.14 & -10.49 \\
\hline 岇 & Cross-snenti & PON & -6.43 & -1.04 & -2.87 & -4.1 & -14.44 \\
\hline Z & Along-shelf & DIN & 0.97 & 2.52 & -13.05 & 10.23 & 0.67 \\
\hline \& & Along-snelI & PON & 7.03 & 1.15 & -10.68 & 9.02 & 6.34 \\
\hline & Denitrification & & -12.85 & -6.25 & -73.66 & -24.27 & -117.04 \\
\hline & $\begin{array}{l}\text { f abbreviations: BOC } \\
\text { WFS: West Florida } \\
\text { an value through the } \\
\text { re. } \\
\text { ean value through the } \\
\text { Denitrification rates ar }\end{array}$ & $\begin{array}{l}\text { ay of Campect } \\
\text { er column alor } \\
\text { ter column alc }\end{array}$ & $\begin{array}{l}\mathrm{m} \text { isobath, TAVE: } \\
0 \mathrm{~m} \text { isobath } \\
\text { the sedime }\end{array}$ & $\begin{array}{l}\text { maulipas } \\
\text { r cross-sl } \\
\text { or along- }\end{array}$ & $\begin{array}{l}\text { racruz she } \\
\text { DIN/PON } \\
\text { If DIN/PC }\end{array}$ & $\begin{array}{l}\text { ATEX: Lo } \\
\text { sport, +: } \\
\text { insport, +: }\end{array}$ & $\begin{array}{l}\text { na-Texas } \\
\text { re, -: } \\
\text { gain, -: net } \\
\text { sented in }\end{array}$ \\
\hline
\end{tabular}

riverine nutrient input into the model domain (US rivers are based on USGS observation, and Mexican and Cuban rivers are based on climatology, see the Methods section for more details), denitrification (coupled nitrification/denitrification), and dominant physical transport processes (see Table 1 for nitrogen flux and Table 2 for nitrogen budget). 


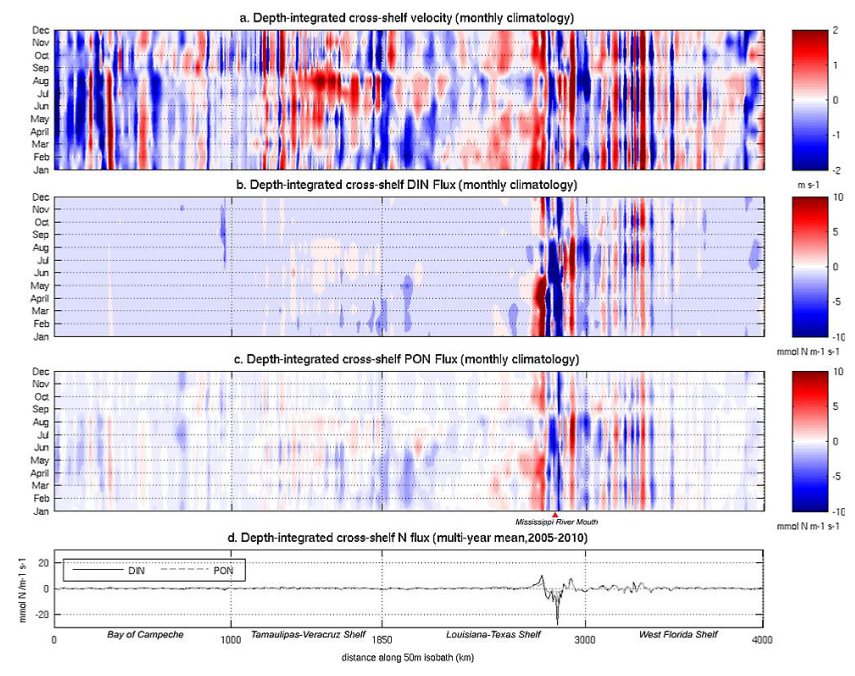

Fig. 12. Depth-integrated monthly mean cross-shelf (a) velocity, (b) DIN flux, (c) PON flux and (d) annual mean DIN and PON flux cross the $50 \mathrm{~m}$ isobath. Positive/negative values stand for shoreward/seaward transport.

\subsubsection{BOC shelf}

BOC is the southernmost semi-enclosed region in the GoM. Estimated nitrogen loading was $12.42 \times 10^{9} \mathrm{~mol} \mathrm{~N} \mathrm{yr}^{-1}$ (Tables 1 and 2), the majority of which was discharged by the Usumacinta River. Mean (averaged over 2005-2010) nitrogen loading in spring, summer, fall, and winter were $1.41,4.30,4.19$ and $2.52 \times 10^{9} \mathrm{~mol} \mathrm{~N}$ respectively. Consistent with findings of earlier studies (Zavala-Hidalgo et al., 2003; Morey et al., 2005), our results identify two prevailing circulation patterns in the BOC. In the northeast, upwelling favorable winds and upcoast currents (flowing in the direction with coast to the left) occupy the Campeche Bank throughout the year. The westward winds and associated current induced significant along-shelf transport, bringing $8.40 \times 10^{9} \mathrm{~mol} \mathrm{~N} \mathrm{yr}^{-1}$ (DIN and PON combined, unless otherwise indicated) into the $\mathrm{BOC}$ at the east end of the BOC shelf (Fig. 13). West of the Campeche Bank the coastline is directed north-south, thus the westward current induced an overall offshore nitrogen flux throughout the year $\left(7.82 \times 10^{9} \mathrm{~mol} \mathrm{Nyr}^{-1}\right)$. In the center of the BOC, there is a permanent wind-driven cyclonic circulation (Vazquez de la Cerda et al., 2005), which tends to increase during autumn to winter months. At the same time, a strong downcoast (flowing in the direction with coast to the right) current traveled into the southernmost part of the BOC (Fig. 13c), causing a local convergence on the inner shelf. This alongshelf current transported $0.17 \times 10^{9} \mathrm{molN}$ from the TAVE shelf to the BOC shelf. In the following winter, spring, and summer months, offshore cyclonic circulation weakened, while the upcoast current from the Campeche Bank gradually strengthened (Fig. 13a, b, d), transporting $0.17 \times 10^{9} \mathrm{~mol} \mathrm{~N}$
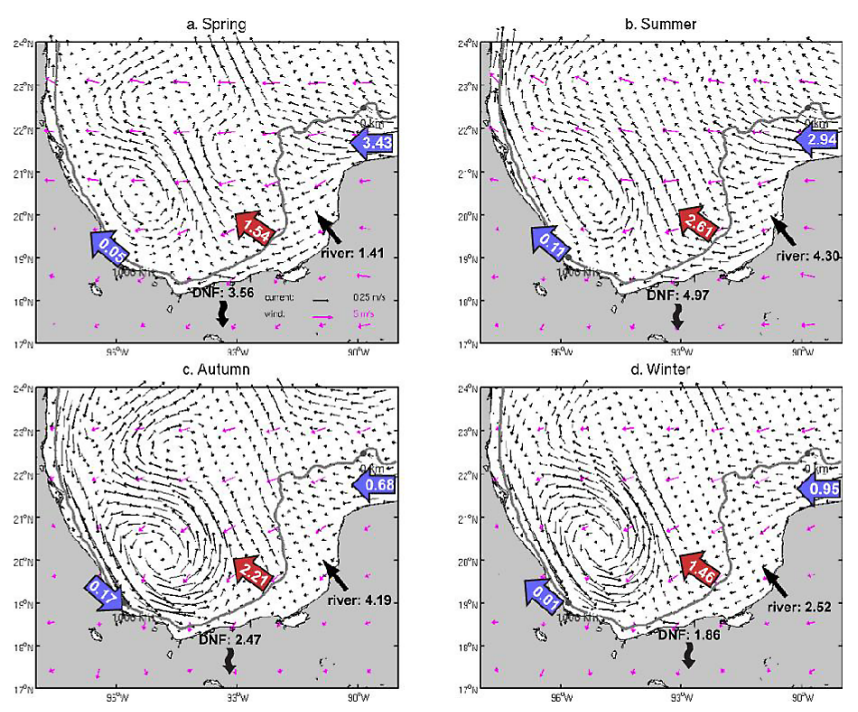

Fig. 13. Seasonal mean surface current and wind fields in the BOC shelf in (a) spring, (b) summer, (c) autumn, and (d) winter. Also shown is regional along-shelf nitrogen transport (blue arrows, unit: $10^{9} \mathrm{~mol} \mathrm{~N}$ ), cross-shelf nitrogen transport (red arrows, unit: $10^{9} \mathrm{~mol} \mathrm{~N}$ ), river inputs (unit: $10^{9} \mathrm{~mol} \mathrm{~N}$ ) and nitrogen removed by denitrification (DNF, unit: $10^{9} \mathrm{~mol} \mathrm{~N}$ ), and $50 \mathrm{~m}$ isobath (grey line).

back to the TAVE shelf (winter, spring, and summer months combined). The BOC had the smallest denitrification rate among the four shelf sections $\left(0.48 \mathrm{mmol} \mathrm{N} \mathrm{m}^{-2} \mathrm{~d}^{-1}\right.$, multiyear mean, Table 2). The rate peaks during summer months $\left(0.78 \mathrm{mmol} \mathrm{N} \mathrm{m}^{-2} \mathrm{~d}^{-1}\right)$. The total amount of the DIN removed by denitrification was $12.85 \times 10^{9} \mathrm{~mol} \mathrm{~N} \mathrm{yr}^{-1}$, which closely balanced the nitrogen loading from local rivers.

\subsubsection{TAVE shelf}

The TAVE shelf has no major river, and thus received the least riverine nitrogen input into the GoM $(\sim$ only $1.83 \times 10^{9} \mathrm{~mol} \mathrm{~N} \mathrm{yr}^{-1}$, Table 2 ). Our results confirm that the circulation in the TAVE shelf (Fig. 14) is characterized by a flow reversal from upcoast circulation in spring-summer season to downcoast circulation in fall-winter season (ZavalaHidalgo et al., 2003; DiMarco et al., 2005; Vazquez de la Cerda et al., 2005; Morey et al., 2005). During spring the shelf was characterized by easterly winds, upcoast currents, and an offshore nutrient transport of $0.12 \times 10^{9} \mathrm{~mol} \mathrm{~N}$. The upcoast currents peaked during summer months when southeasterly wind prevails, transporting $1.5 \times 10^{9} \mathrm{molN}$ to the LATEX shelf. This strong southeasterly wind also induced strong shoreward nitrogen flux $\left(4.07 \times 10^{9} \mathrm{~mol} \mathrm{~N}\right.$ in summer). In fall, easterly to northeast wind prevailed both the TAVE and LATEX shelves to the north, reversing the coastal flow on the TAVE shelf from upcoast to downcoast. Along-shelf currents from the LATEX shelf brought $4.55 \times 10^{9} \mathrm{~mol} \mathrm{~N}$ (fall and winter combined) to the TAVE shelf. The downcoast flow is accompanied by a net 

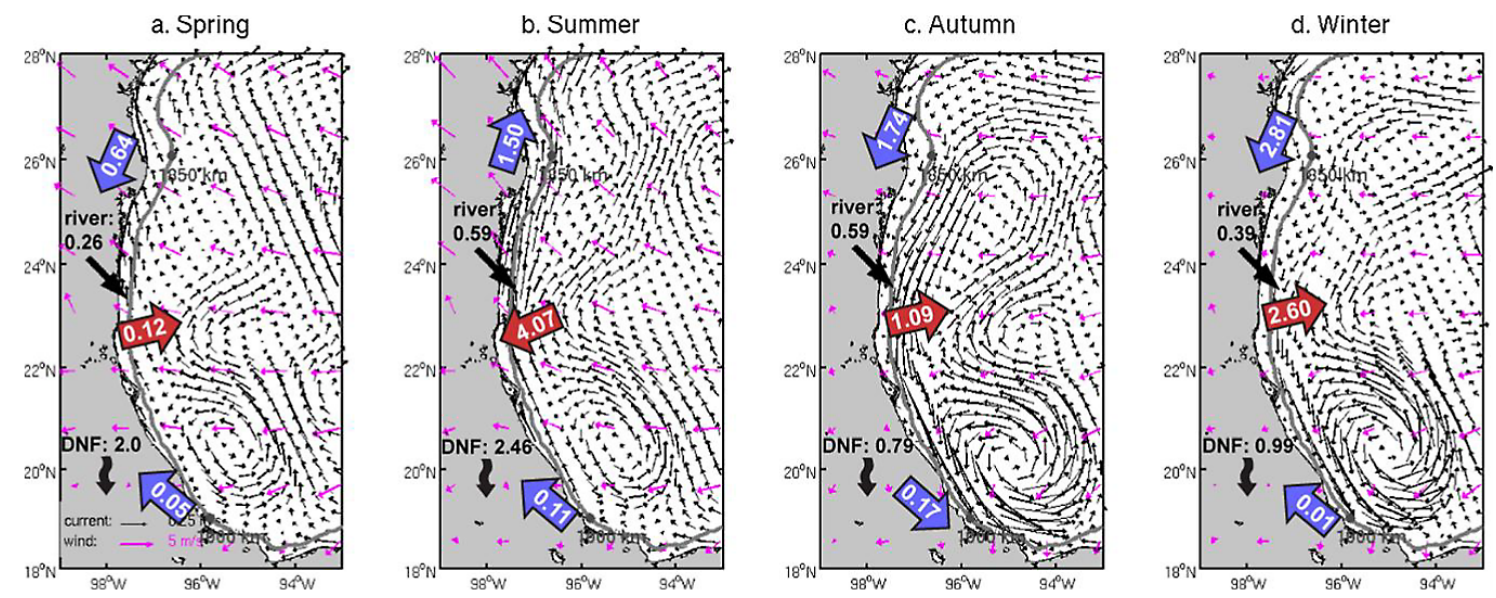

Fig. 14. Similar to Fig. 13 but for the TAVE shelf.

offshore nitrogen flux in fall and winter, which amounted to $3.69 \times 10^{9} \mathrm{~mol} \mathrm{~N}$ to the deep sea. Due to the limited width, denitrification on the TAVE shelf was smallest among the four shelf sections $\left(6.25 \times 10^{9} \mathrm{~mol} \mathrm{~N} \mathrm{yr}^{-1}\right.$, Table 2$)$.

\subsubsection{LATEX shelf}

Our calculations indicated that the LATEX shelf received 0.78 billion tons of freshwater and $108.86 \times 10^{9} \mathrm{~mol} \mathrm{~N}$ annually (averaged over 2005-2010). More than $90 \%$ of these river inputs were from the Mississippi-Atchafalaya river system, which had peak discharge values in spring months $\left(42.68 \times 10^{9} \mathrm{~mol} \mathrm{~N}\right.$, Tables 1 and 2). Despite the large riverine input, the multiyear mean net flux calculation indicated $73.66 \times 10^{9} \mathrm{~mol} \mathrm{~N}$ was denitrified on the inner shelf, which is an equivalent of $\sim 67.7 \%$ of the riverine nitrogen (Table 2). $23.73 \times 10^{9} \mathrm{~mol} \mathrm{~N} \mathrm{yr}^{-1}$, an equivalent of $\sim 21.7 \%$ of the riverine nitrogen, was transported to either the TAVE shelf in the west or the WFS in the east through along-shelf flows; $13.1 \times 10^{9} \mathrm{~mol} \mathrm{~N} \mathrm{yr}^{-1}$, an equivalent of $\sim 12.0 \%$ of the riverine input was exported offshore to the deep ocean, mainly in association with waters southwest of the Mississippi River delta (Figs. 8, 15).

Our simulation results support other observations that the inner LATEX shelf is dominated by downcoast winds in nonsummer months (e.g., Cho et al., 1998; Zavala-Hidalgo et al., 2003; Morey et al., 2005; Fig. 15a, c, d). The correlation between monthly averaged currents and along-shelf wind stress was positive and highly significant (Nowlin et al., 2005). In spring, the upcoast currents from the northern TAVE shelf encountered the downcoast currents from the LATEX shelf, forming a confluence zone and a high chlorophyll anomaly can also be seen in the monthly climatology of SeaWiFS ocean color maps (Martinez-Lopez and ZavalaHidalgo, 2009). However, no prominent offshore transport was seen in either seasonal chlorophyll climatology (Fig. 8) or cross-shelf velocity (Fig. 12a) at this location.
The outer LATEX shelf is more influenced by its interaction with LC eddies (e.g., Ohlmann et al., 2001; Nowlin et al., 2005), which can bring large temporal and spatial variability to the current fields along the $50 \mathrm{~m}$ isobath. Despite such variability, strong offshore nitrogen export was seen in areas around the Mississippi Delta almost throughout the year (Fig. 12). In addition to offshore export, the LATEX shelf continuously delivered nitrogen to the adjacent TAVE shelf $\left(5.19 \times 10^{9} \mathrm{~mol} \mathrm{~N}\right.$, fall, winter, and spring combined $)$ and WFS $\left(20.22 \times 10^{9} \mathrm{~mol} \mathrm{~N} \mathrm{yr}^{-1}\right)$ throughout most of the year. As previously described, westward along-shelf flow on the western LATEX shelf during non-summer months continuously transported nitrogen to the TAVE shelf. The only exception was during summer months when the winds changed to northwestward, and currents on the western LATEX shelf shifted to the upcoast direction (Fig. 15b). East of the Mississippi Delta, the along-shelf currents also flowed eastward, transporting materials from the LATEX shelf to the WFS. This nitrogen flux reached its annual maximum $\left(8.81 \times 10^{9} \mathrm{~mol} \mathrm{~N}\right)$ in summer.

\subsubsection{WFS}

Circulation of the WFS is influenced by both local and deep-ocean LC forcing. Our $6 \mathrm{yr}$ mean wind and surface current fields (Fig. 16) reproduced many known features identified in earlier studies (e.g., He and Weisberg, 2002, 2003; Weisberg et al., 2005). Annual riverine nitrogen input $\left(12.76 \times 10^{9} \mathrm{~mol} \mathrm{Nyr}^{-1}\right)$ to the WFS was comparable to that to the BOC shelf $\left(12.42 \times 10^{9} \mathrm{~mol} \mathrm{~N} \mathrm{yr}^{-1}\right.$, Table 2$)$. The riverine nitrogen loading peaks in summer months $\left(7.27 \times 10^{9} \mathrm{molN}\right)$. Depth integrated currents and nitrogen flux at the $50 \mathrm{~m}$ isobath were characterized by significant spatial variability at the Mississippi-Alabama-Florida junction and a mean offshore transport from the west Florida (Fig. 12). Previous studies provided evidence that the shelf off the states of Mississippi, Alabama, and Florida receives 

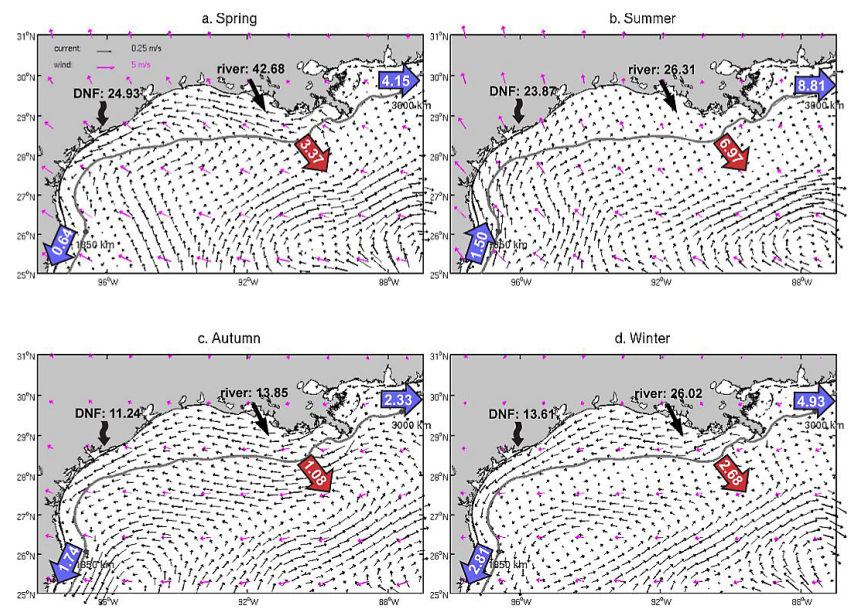

Fig. 15. Similar to Fig. 13 but for the LATEX shelf.

a large amount of low salinity water from the Mississippi River during summer months (e.g., Morey et al., 2003, 2005). A low salinity "tongue" is formed as a result of intensive cross-shelf freshwater export (e.g., Morey et al., 2003) and can be identified as a patch of high chlorophyll waters flowing to the south/southeast (Fig. 8). The 6 yr mean offshore nitrogen flux was $4.24 \times 10^{9} \mathrm{~mol} \mathrm{~N} \mathrm{yr}^{-1}$. Unlike the LATEX shelf, the offshore nitrogen flux at WFS is dominated by PON export $(\sim 96.7 \%)$. Not surprisingly, the along-shelf nitrogen flux from the LATEX shelf $\left(20.22 \times 10^{9} \mathrm{~mol} \mathrm{~N} \mathrm{yr}^{-1}\right)$ is the major nitrogen source for the WFS. Denitrification removed $24.27 \times 10^{9} \mathrm{~mol} \mathrm{~N}$ on the WFS annually, which is largely balanced by the combination of local river inputs and nitrogen transported from the LATEX shelf.

\subsubsection{Gulf-wide results}

Our calculations show that the GoM shelves receives $142.88 \times 10^{9} \mathrm{molN}$ annually, the majority of which was input by local rivers $\left(135.87 \times 10^{9} \mathrm{~mol} \mathrm{Nyr}^{-1}\right)$ and the rest $\left(7.01 \times 10^{9} \mathrm{~mol} \mathrm{Nyr}^{-1}\right)$ is from the open ocean. On an annual basis, the magnitude of riverine input was roughly balanced by denitrification and cross-shelf export $\left(141.97 \times 10^{9} \mathrm{~mol} \mathrm{Nyr}^{-1}\right)$. We attribute the small residual difference $\left(0.91 \times 10^{9} \mathrm{~mol} \mathrm{~N} \mathrm{yr}^{-1}\right.$, or $<1 \%$ of the annual nitrogen input) between shelf nitrogen input and removal to either lateral diffusion or computational errors of the model integration. Denitrification (coupled nitrificationdenitrification) accounts for over $80 \%$ of the nitrogen removal from the water column $\left(117.04 \times 10^{9} \mathrm{~mol} \mathrm{~N} \mathrm{yr}^{-1}\right)$. The shelf-wide denitrification rate was estimated to be $1.04 \mathrm{mmol} \mathrm{N} \mathrm{m}^{-2} \mathrm{~d}^{-1}$, which was comparable to that in the Middle Atlantic Bight $\left(0.92 \mathrm{mmol} \mathrm{N} \mathrm{m}^{-2} \mathrm{~d}^{-1}\right.$, Fennel et al., 2008) and Massachusetts Bay in the Gulf of Maine (1.3 mmol $\mathrm{m}^{-2} \mathrm{~d}^{-1}$, Hopkinson et al., 2001). Among the four shelf sections, the LATEX shelf has the highest denitrification rate $\left(1.84 \mathrm{mmol} \mathrm{N} \mathrm{m}^{-2} \mathrm{~d}^{-1}\right)$ corresponding to the
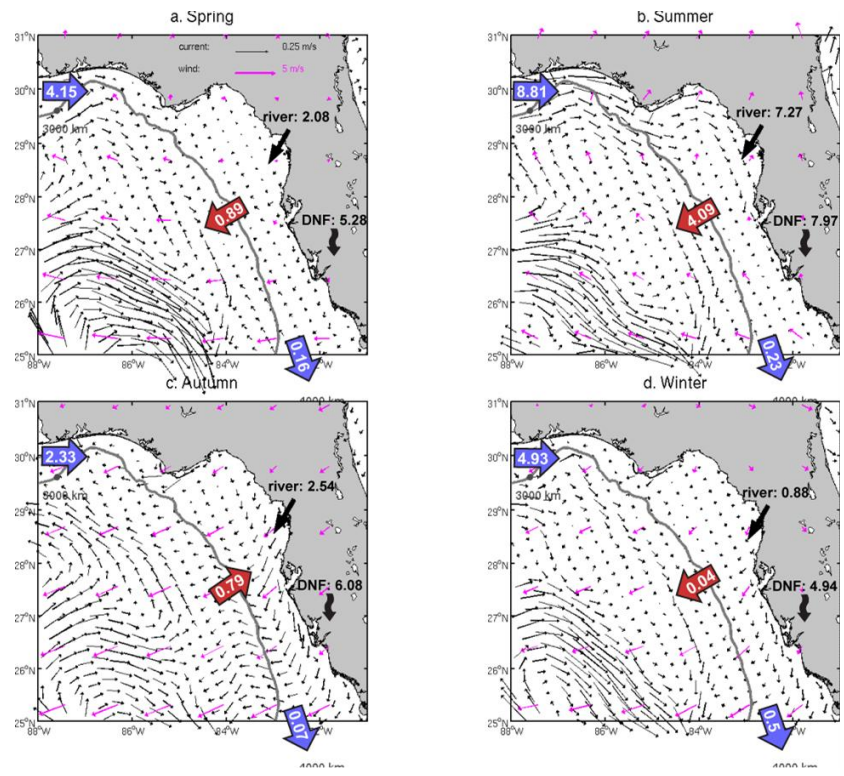

Fig. 16. Similar to Fig. 13 but for the West Florida Shelf.

largest local river inputs, and concomitantly the largest organic N export to the bottom sediments. For both WFS and TAVE shelves, a large part of the denitrified nitrogen (both PON and DIN) was from the adjacent LATEX shelf through along-shelf transport. On the BOC shelf, aside from local river inputs, an important nitrogen source was the PON transported in the along-shelf direction from waters in the east.

Our calculations also support the view that the gulfwide mean cross-shelf nitrogen exchange between the inner shelf and deep ocean is seaward. On an annual basis, the amount of the nitrogen exported from the shelf $\left(24.93 \times 10^{9} \mathrm{~mol} \mathrm{~N} \mathrm{yr}^{-1}\right)$ was an equivalent of $\sim 17 \%$ of that received from local rivers and along-shelf transport. Acrossshelf nitrogen flux changes its onshore/offshore direction seasonally on the TAVE shelf and WFS, but remains persistently offshore on LATEX and BOC shelves.

\section{Summary and conclusions}

We coupled a seven-component marine ecosystem model with a three-dimensional high-resolution circulation model for the Gulf of Mexico and South Atlantic Bight. The coupled physical-biogeochemical modeling system was used to hindcast the GoM circulation and biogeochemical variations from January 2004 to December 2010. Favorable comparisons were found when validating model hindcast solutions against satellite observed surface chlorophyll and sea surface height, and extensive in situ measurements including sea level, temperature, salinity, and nutrients, indicating that the coupled model can resolve the major physical and biogeochemical dynamics of the GoM. Time and space continuous hindcast fields from January 2005 to December 2010 were 
then used to investigate the temporal and spatial characteristics of the GoM circulation and ecosystem variability.

Clear seasonality and interannual variability was seen in riverine freshwater and nitrogen input. While significant temporal correlations were found between riverine input and DIN concentration on the shelf, no clear correlation was seen between river loading and surface DIN concentration in the deep ocean. EOF analyses revealed that the largest variability in DIN and plankton distributions occurred in the northern GoM. PC1s of the EOF analyses were indicative of a phase-locked pattern common all aquatic ecosystem where DIN variations generally lead phytoplankton variations with a $0-1$ month lag, which in turn lead to zooplankton variations with a further $0-1$ month lag.

A shelf nitrogen budget was developed based on the multiyear mean conditions over 2005-2010. Based on our estimated flux, we concluded that riverine nitrogen input is largely balanced by the removal through denitrification. Along-shelf transport played an important role in distributing the large nitrogen load in the LATEX shelf to adjacent WFS and TAVE shelves. Persistent cross-shelf exchange was seen between the shelf and deep ocean. Regions off the BOC, Mississippi River delta and in the Mississippi-Alabama-Florida junction were identified as major nitrogen export sites. On an annual basis, the amount of exported nitrogen was equivalent to $17 \%$ of that received from rivers and along-shelf transport.

Our study provides a modeling framework to examine important hydrologic-physical-biogeochemical coupling processes in the GoM, allowing for an integrated understanding of regional marine ecosystem responses to a broad spectrum of processes, ranging from extreme synoptic weather events (e.g., hurricanes) to climate and land use changes. We note however that the complexity of the food web and uncertainties in model parameterizations remain an active research topic in coupled physical-biogeochemical modeling. For instance, we have not considered the process of nitrogen fixation process by cyanobacteria (Walsh et al., 1989; Mulholland et al., 2006) and our description of dissolved organic nitrogen is still rudimentary. The lack of accounting for phosphate and silicate compartments in the ecosystem model may compromise the model's ability and accuracy in simulating phytoplankton population dynamics and the coupling to higher trophic levels. Improved marine biogeochemical modeling skill can be further achieved with refinement of model process/parameterizations and advances in observational infrastructure (e.g., more rapid and accurate nutrient sensors) together with sophisticated techniques for data assimilation.
Acknowledgements. Research support provided through NASA grants NNX10AU06G and NNX12AP84G; NOAA grant NA11NOS0120033, and GRI GISR grant SA/GoMRI-006 is much appreciated. We thank our editor, Marilaure Grégoire, and two reviewers, Matthew Howard (TAMU) and Sergio deRada (NRL), for their constructive comments and suggestions that helped improve this manuscript. K. Chen (WHOI), Z. Yao (OUC), and Y. Li (NCSU) are also acknowledged for useful discussions.

Edited by: M. Grégoire

\section{References}

Aulenbach, B. T., Buxton, H. T., Battaglin, W. T., and Coupe, R. H.: Streamflow and nutrient fluxes of the Mississippi-Atchafalaya River Basin and subbasins for the period of record through 2005, US Geological Survey Open-File Report 2007-1080, 2007.

Bianchi, T., DiMarco, S., Cowan Jr., J., Hetland, R., Chapman, P., Day, J., and Allison, M.: The science of hypoxia in the Northern Gulf of Mexico: a review, Sci. Total Environ., 408, 1471-1484, doi:10.1016/j.scitotenv.2009.11.047, 2010.

Cai, W.-J., Hu, X., Huang, W.-J., Murrell, M. C., Lehrter, J. C., Lohrenz, S. E., Chou, W.-C., Zhai, W., Hollibaugh, J. T., Wang, Y., Zhao, P., Guo, X., Gundersen, K., Dai, M., and Gong, G.-C.: Acidification of subsurface coastal waters enhanced by eutrophication, Nat. Geosci., 4, 766-770, 2011.

CENR (Committee on Environmental and Natural Resources): Integrated Assessment of Hypoxia in the Northern Gulf of Maxico, Washington, DC, 48, 2000.

Chassignet, E. P., Hurlburt, H. E., Smedstad, O. M., Halliwell, G. R., Hogan, P. J., Wallcraft, A. J., Baraille, R., and Bleck, R.: The HYCOM (HYbrid Coordinate Ocean Model) data assimilative system, J. Mar. Syst., 65, 60-83, 2007.

Cho, K. W., Reid, R. O., and Nowlin, W. D.: Objectively mapped stream function fields on the Texas-Louisiana shelf based on 32 months of moored current meter data, J. Geophys. Res.-Oceans, 103, 10377-10390, 1998.

DaSilva, A., Younga, A. C., and Levitus, S.: Atlas of Surface Marine Data 1994, Volume 1: Algorithms and Procedures, 1994.

DiMarco, S., Nowlin, W., and Reid, R. O.: A statistical description of the velocity fields from upper ocean drifter in the Gulf of Mexico, in: Circulation in the Gulf of Mexico: Observations and Models, Geophys. Monogr. Ser., AGU, Washington, DC, 101110, 2005.

DiMarco, S. F., Chapman, P., Walker, N., and Hetland, R. D.: Does local topography control hypoxia on the eastern Texas-Louisiana shelf?, J. Mar. Syst., 80, 25-35, 2010.

Egbert, G. D. and Erofeeva, S. Y.: Efficient Inverse Modeling of Barotropic Ocean Tides, J. Atmos. Ocean. Tech., 19, 183-204, doi:10.1175/1520-0426(2002)019<0183:EIMOBO>2.0.CO;2, 2002.

Fasham, M. J. R., Sarmiento, J. L., Slater, R. D., Ducklow, H. W., and Williams, R.: Ecosystem behavior at Bermuda Station "S" and ocean weather station "India": A general circulation model and observational analysis, Global Biogeochem. Cy., 7, 379-415, doi:10.1029/92GB02784, 1993.

Fennel, K., Wilkin, J., Levin, J., Moisan, J., O'Reilly, J., and Haidvogel, D. B.: Nitrogen cycling in the Middle Atlantic Bight: results from a three-dimensional model and implications for the 
North Atlantic nitrogen budget, Global Biogeochem. Cy., 20, GB3007, doi:10.1029/2005GB002456, 2006.

Fennel, K., Wilkin, J., Previdi, M., and Najjar, R.: Denitrification effects on air-sea $\mathrm{CO}_{2}$ flux in the coastal ocean: simulations for the Northwest North Atlantic, Geophys. Res. Lett., 35, L24608, doi:10.1029/2008GL036147, 2008.

Fennel, K., Hetland, R., Feng, Y., and DiMarco, S.: A coupled physical-biological model of the Northern Gulf of Mexico shelf: model description, validation and analysis of phytoplankton variability, Biogeosciences, 8, 1881-1899, doi:10.5194/bg-8-18812011, 2011.

Fennel, K., Hu, J., Laurent, A., Marta-Almeida, M., and Hetland, R.: Sensitivity of hypoxia predictions for the northern Gulf of Mexico to sediment oxygen consumption and model nesting, J. Geophys. Res.-Oceans, 118, 990-1002, doi:10.1002/jgrc.20077, 2013.

Flather, R. A.: A tidal model of the northwest European continental shelf, Mem. Soc. R. Sci. Liege, 10, 141-164, 1976.

Fuentes-Yaco, C., de Leon, D. A. S., Monreal-Gomez, M. A., and Vera-Herrera, F.: Environmental forcing in a tropical estuarine ecosystem: the Palizada River in the southern Gulf of Mexico, Mar. Freshwater Res., 52, 735-744, 2001.

Garcia, H. E., Locarnini, R. A., Boyer, T. P., Antonov, J. I., Zweng, M. M., Baranova, O. K., and Johnson, D. R.: World Ocean Atlas 2009, NOAA Atlas NESDIS 71, edited by: Levitus, S., US Government Printing Office, Washington DC, 398 pp., 2010.

Gattuso, J. P., Frankignoulle, M., and Wollast, R.: Carbon and Carbonate Metabolism in Coastal Aquatic Ecosystems, Annu. Rev. Ecol. Syst., 29, 405-434, 1998.

Gilbes, F., Tomas, C., Walsh, J. J., and MullerKarger, F. E.: An episodic chlorophyll plume on the West Florida Shelf, Cont. Shelf Res., 16, 1201-1224, 1996.

Goolsby, D. A., Battaglin, W. A., Aulenbach, B. T., and Hooper, R. P.: Nitrogen input to the Gulf of Mexico, J. Environ. Qual., 30, 329-336, 2001.

Guo, X. H., Cai, W. J., Huang, W. J., Wang, Y. C., Chen, F. Z., Murrell, M. C., Lohrenz, S. E., Jiang, L. Q., Dai, M. H., Hartmann, J., Lin, Q., and Culp, R.: Carbon dynamics and community production in the Mississippi River plume, Limnol. Oceanogr., 57, 1-17, 2012.

Haidvogel, D. B., Arango, H., Budgell, W. P., Cornuelle, B. D., Curchitser, E., Di Lorenzo, E., Fennel, K., Geyer, W. R., Hermann, A. J., Lanerolle, L., Levin, J., McWilliams, J. C., Miller, A. J., Moore, A. M., Powell, T. M., Shchepetkin, A. F., Sherwood, C. R., Signell, R. P., Warner, J. C., and Wilkin, J.: Ocean forecasting in terrain-following coordinates: Formulation and skill assessment of the Regional Ocean Modeling System, J. Comput. Phys., 227, 3595-3624, 2008.

He, R. Y. and Weisberg, R. H.: West Florida shelf circulation and temperature budget for the 1999 spring transition, Cont. Shelf Res., 22, 719-748, 2002.

He, R. Y. and Weisberg, R. H.: West Florida shelf circulation and temperature budget for the 1998 fall transition, Cont. Shelf Res., 23, 777-800, 2003.

Heileman, S. and Rabalais, N.: XV-50 Gulf of Mexico LME, United Nations Environment Programme, Nairobi, Kenya, 673$688,2008$.
Hopkinson, C., Giblin, A., Tucker J.: Benthic metabolism and nutrient regeneration on the continental shelf of Eastern Massachusetts, USA, Mar. Ecol.-Prog. Ser., 224, 1-19, 2001.

Huang, W.-J., Cai, W.-J., Powell, R. T., Lohrenz, S. E., Wang, Y., Jiang, L.-Q., and Hopkinson, C. S.: The stoichiometry of inorganic carbon and nutrient removal in the Mississippi River plume and adjacent continental shelf, Biogeosciences, 9, 2781-2792, doi:10.5194/bg-9-2781-2012, 2012.

Huang, W. J., Cai, W. J., Castelao, R. M., Wang, Y., and Lohrenz, S. E.: Impacts of a wind-driven cross-shelf large river plume on biological production and $\mathrm{CO}_{2}$ update in the Gulf of Mexico during spring, Limnol. Oceanogr., 58, 1727-1735, 2013.

Hyun, K. H. and He, R.: Coastal upwelling in the South Atlantic Bight: A revisit of the 2003 cold event using long term observations and model hindcast solutions, J. Mar. Syst., 83, 1-13, 2010.

Jolliff, J. K., Walsh, J. J., He, R. Y., Weisberg, R., Stovall-Leonard, A., Coble, P. G., Conmy, R., Heil, C., Nababan, B., Zhang, H. Y., Hu, C. M., and Muller-Karger, F. E.: Dispersal of the Suwannee River plume over the West Florida shelf: Simulation and observation of the optical and biochemical consequences of a flushing event, Geophys. Res. Lett., 30, 1709, doi:10.1029/2003GL0169642003.

Jolliff, J. K., Kindle, J. C., Penta, B., Helber, R., Lee, Z., Shulman, I., Arnone, R., and Rowley, C. D.: On the relationship between satellite-estimated bio-optical and thermal properties in the Gulf of Mexico, J. Geophys. Res.-Biogeo., 113, G01024, doi:10.1029/2006JG000373, 2008.

Laurent, A., Fennel, K., Hu, J., and Hetland, R.: Simulating the effects of phosphorus limitation in the Mississippi and Atchafalaya River plumes, Biogeosciences, 9, 4707-4723, doi:10.5194/bg-94707-2012, 2012.

Lehrter, J. C., Murrell, M. C., and Kurtz, J.: Interactions between freshwater input, light, and phytoplankton dynamics on the Louisiana continental shelf, Cont. Shelf Res., 29, 1861-1872, 2009.

Lehrter, J. C., Beddick, D. L., Devereux, R., Yates, D. F., and Murrell, M. C.: Sediment-water fluxes of dissolved inorganic carbon, $\mathrm{O}_{2}$, nutrients, and $\mathrm{N}_{2}$ from the hypoxic region of the Louisiana continental shelf, Biogeochemistry, 109, 233-252, 2012.

Liu, K. K., Atkinson, L. P., Quinones, R., and Talaue-McManus, L.: Carbon and Nutrient Fluxes in Continental Margins: A Global Synthesis, IGBP Book Series, Springer, Berlin, 2010.

Lohrenz, S. E., Fahnenstiel, G. L., Redalje, D. G., Lang, G. A., Chen, X. G., and Dagg, M. J.: Variations in primary production of northern Gulf of Mexico continental shelf waters linked to nutrient inputs from the Mississippi River, Mar. Ecol.-Prog. Ser., 155, 45-54, 1997.

Lohrenz, S., Fahnenstiel, G., Redalje, D., Lang, G., Dagg, M., Whitledge, T., and Dortch, Q.: Nutrients, irradiance, and mixing as factors regulating primary production in coastal waters impacted by the Mississippi River plume, Cont. Shelf Res., 19, 1113-1141, 1999.

Lohrenz, S. E., Redalje, D. G., Cai, W. J., Acker, J., and Dagg, M.: A retrospective analysis of nutrients and phytoplankton productivity in the Mississippi River plume, Cont. Shelf Res., 28, 14661475, 2008.

Marchesiello, P., McWilliams, J. C., and Shchepetkin, A.: Open boundary conditions for long-term integration of regional oceanic models, Ocean Model., 3, 1-20, 2001. 
Martinez-Lopez, B. and Zavala-Hidalgo, J.: Seasonal and interannual variability of cross-shelf transports of chlorophyll in the Gulf of Mexico, J. Mar. Syst., 77, 1-20, 2009.

McGillicuddy, D. J., Anderson, L. A., Doney, S. C., and Maltrud, M. E.: Eddy-driven sources and sinks of nutrients in the upper ocean: Results from a $0.1^{\circ}$ resolution model of the North Atlantic, Global Biogeochem. Cy., 17, 1035, doi:10.1029/2002GB001987, 2003.

Mellor, G. L. and Yamada, T.: Development of a turbulence closure model for geophysical fluid problems, Rev. Geophys., 20, 851$875,1982$.

Milliman, J. D. and Farnsworth, K. L.: River discharge to the coastal ocean : a global synthesis, Cambridge University Press, Cambridge, New York, viii, 384 pp., 2011.

Morey, S. L., Martin, P. J., O'Brien, J. J., Wallcraft, A. A., and Zavala-Hidalgo, J.: Export pathways for river discharged fresh water in the northern Gulf of Mexico, J. Geophys. Res.-Oceans, 108, 3303, doi:10.1029/2002JC001674, 2003.

Morey, S. L., Zavala-Hidalgo, J., and O'Brien, J. J.: The seasonal variability of continental shelf circulation in the northern and western Gulf of Mexico from a high-resolution numerical model, in: Circulation in the Gulf of Mexico: Observations and Models, Geophys. Monogr. Ser., AGU, Washington, DC, 203-218, 2005.

Mulholland, M. R., Bernhardt, P. W., Heil, C. A., Bronk, D. A., and O'Neil, J. M.: Nitrogen fixation and release of fixed nitrogen by Trichodesmium spp. in the Gulf of Mexico, Limnol. Oceanogr., 51, 1762-1776, 2006.

Muller-Karger, F. E., Walsh, J. J., Evans, R. H., and Meyers, M. B.: On the Seasonal Phytoplankton Concentration and Sea-Surface Temperature Cycles of the Gulf of Mexico as Determined by Satellites, J. Geophys. Res.-Oceans, 96, 12645-12665, 1991.

Nababan, B., Muller-Karger, F. E., Hu, C., and Biggs, D. C.: Chlorophyll variability in the northeastern Gulf of Mexico, Int. J. Remote Sens., 32, 8373-8391, do:10.1080/01431161.2010.542192, 2011.

Nixon, S. W., Ammerman, J. W., Atkinson, L. P., Berounsky, V. M., Billen, G., Boicourt, W. C., Boynton, W. R., Church, T. M., Ditoro, D. M., Elmgren, R., Garber, J. H., Giblin, A. E., Jahnke, R. A., Owens, N. J. P., Pilson, M. E. Q., and Seitzinger, S. P.: The fate of nitrogen and phosphorus at the land sea margin of the North Atlantic Ocean, Biogeochemistry, 35, 141-180, 1996.

Nowlin, W., Jochens, A. E., DiMarco, S., Reid, R. O., and Howard, M. K.: Low-frequency circulation over the Texas-Louisiana continental shelf, in: Circulation in the Gulf of Mexico: Observations and Models, Geophys. Monogr. Ser., AGU, Washington, DC, 219-240, 2005.

Ohlmann, J. C., Niiler, P. P., Fox, C. A., and Leben, R. R.: Eddy energy and shelf interactions in the Gulf of Mexico, J. Geophys. Res.-Oceans, 106, 2605-2620, 2001.

Rabalais, N., Turner, R. E., and Wiseman, W. J. J.: GULF OF MEXICO HYPOXIA, A.K.A. THE DEAD ZONE, Annu. Rev. Ecol. Syst., 33, 235-263, 2002.
Rabalais, N. N., Turner, R. E., Sen Gupta, B. K., Boesch, D. F., Chapman, P., and Murrell, M. C.: Hypoxia in the northern Gulf of Mexico: Does the science support the plan to reduce, mitigate, and control hypoxia?, Estuar. Coasts, 30, 753-772, 2007.

Seitzinger, S. P. and Giblin, A. E.: Estimating denitrification in North Atlantic continental shelf sediments, Biogeochemistry, 35, 235-260, 1996.

Shchepetkin, A. F. and McWilliams, J. C.: The Regional Ocean Modeling System (ROMS): a split-explicit, free-surface, topography-following coordinates ocean model, Ocean Model., 9, 347-404, 2005.

Sturges, W. and Leben, R.: Frequency of Ring Separations from the Loop Current in the Gulf of Mexico: A Revised Estimate, Journal of Physical Oceanography, 30, 1814-1819, 2000.

Taylor, K. E.: Summarizing multiple aspects of model performance in a single diagram, J. Geophys. Res., 106, 7183-7192, 2001.

Toner, M., Kirwan, A. D., Poje, A. C., Kantha, L. H., Muller-Karger, F. E., and Jones, C. K. R. T.: Chlorophyll dispersal by eddy-eddy interactions in the Gulf of Mexico, J. Geophys. Res.-Oceans, 108, 3105, doi:10.1029/2002JC001499, 2003.

Turner, R. and Rabalais, N.: Suspended particulate and dissolved nutrient loadings to Gulf of Mexico estuaries, in: Biogeochemistry of Gulf of Mexico estuaries, edited by: Bianchi, T., Pennock, J., and Twilley, R., John Wiley \& Sons, Inc., New York, 1999.

Vazquez de la Cerda, A. M., Reid, R. O., DiMarco, S. F., and Jochens, A. E.: Bay of Campeche circulation: An update, in: Circulation in the Gulf of Mexico: Observations and Models, Geophys. Monogr. Ser., AGU, Washington, DC, 279-293, 2005.

Walsh, J. J., Dieterle, D. A., Meyers, M. B., and Muller-Karger, F. E.: Nitrogen exchange at the continental margin: A numerical study of the Gulf of Mexico, Progr. Oceanogr., 23, 245-301, 1989.

Weisberg, R., He, R. Y., Liu, Y. G., and Virmani, J. I.: West Florida Shelf circulation on synoptic, seasonal, and Interannual time scales, in: Circulation in the Gulf of Mexico: Observations and Models, Geophys. Monogr. Ser., AGU, Washington, DC, 325347, 2005.

White, J. R., Fulweiler, R. W., Li, C. Y., Bargu, S., Walker, N. D., Twilley, R. R., and Green, S. E.: Mississippi River Flood of 2008: Observations of a Large Freshwater Diversion on Physical, Chemical, and Biological Characteristics of a Shallow Estuarine Lake, Environ. Sci. Technol., 43, 5599-5604, doi:10.1021/es900318t, 2009.

Wiseman, W. J., Rabalais, N. N., Turner, R. E., Dinnel, S. P., and MacNaughton, A.: Seasonal and interannual variability within the Louisiana coastal current: stratification and hypoxia, J. Mar. Syst., 12, 237-248, 1997.

Zavala-Hidalgo, J., Morey, S. L., and O'Brien, J. J.: Seasonal circulation on the western shelf of the Gulf of Mexico using a high-resolution numerical model, J. Geophys. Res., 108, 3389, doi:10.1029/2003JC001879, 2003. 